\title{
Potential Infection Risks of the Wheat Stripe Rust and Stem Rust Pathogens on Barberry in Asia and Southeastern Europe
}

\author{
Parimal Sinha ${ }^{1,2}$ and Xianming Chen ${ }^{2,3, *}$ \\ 1 ICAR-Indian Agricultural Research Institute, New Delhi 110012, India; sinhapath@gmail.com \\ 2 Department of Plant Pathology, Washington State University, Pullman, WA 99164-6430, USA \\ 3 US Department of Agriculture-Agricultural Research Service, Wheat Health, Genetics, and Quality \\ Research Unit, Pullman, WA 99164-6430, USA \\ * Correspondence: xianming.chen@usda.gov; Tel.: +1-509-335-8086
}

Citation: Sinha, P.; Chen, X. Potential Infection Risks of the Wheat Stripe Rust and Stem Rust Pathogens on Barberry in Asia and Southeastern Europe. Plants 2021, 10, 957. https:// doi.org/10.3390/plants10050957

Academic Editors: José Carlos R. Alcantud

Received: 31 March 2021

Accepted: 7 May 2021

Published: 11 May 2021

Publisher's Note: MDPI stays neutral with regard to jurisdictional claims in published maps and institutional affiliations.

Copyright: (c) 2021 by the authors. Licensee MDPI, Basel, Switzerland. This article is an open access article distributed under the terms and conditions of the Creative Commons Attribution (CC BY) license (https:// creativecommons.org/licenses/by/ $4.0 /)$.

\begin{abstract}
Barberry (Berberis spp.) is an alternate host for both the stripe rust pathogen, Puccinia striiformis f. sp. tritici (Pst), and the stem rust pathogen, $P$. graminis f. sp. tritici $(P g t)$, infecting wheat. Infection risk was assessed to determine whether barberry could be infected by either of the pathogens in Asia and Southeastern Europe, known for recurring epidemics on wheat and the presence of barberry habitats. For assessing infection risk, mechanistic infection models were used to calculate infection indices for both pathogens on barberry following a modeling framework. In East Asia, Bhutan, China, and Nepal were found to have low risks of barberry infection by Pst but high risks by Pgt. In Central Asia, Azerbaijan, Iran, Kazakhstan, southern Russia, and Uzbekistan were identified to have low to high risks of barberry infection for both Pst and Pgt. In Northwest Asia, risk levels of both pathogens in Turkey and the Republic of Georgia were determined to be high to very high. In Southwest Asia, no or low risk was found. In Southeastern Europe, similar high or very high risks for both pathogens were noted for all countries. The potential risks of barberry infection by Pst and/or Pgt should provide guidelines for monitoring barberry infections and could be valuable for developing rust management programs in these regions. The framework used in this study may be useful to predict rust infection risk in other regions.
\end{abstract}

Keywords: alternate host; Berberis spp.; Puccinia striiformis f. sp. tritici; Puccinia graminis f. sp. tritici; potential infection risk

\section{Introduction}

Stripe rust and stem rust, caused by Puccinia striiformis f. sp. tritici (Pst) and P. graminis f. sp. tritici $(P g t)$, respectively, are among the most important diseases of wheat worldwide, and they pose major threats to global wheat production [1-3]. Destructive epidemics can occur over vast areas within few weeks if susceptible cultivars are widely grown and weather conditions are favorable to rust [4-7]. In wheat, stripe rust has recently emerged as one of the most destructive diseases [2,8,9]. In the last 15 years, the disease has become one of the largest biotic limitations to wheat production and threatens global food supply. In a study on global incidence of wheat rusts over the past 40 years, Morgounov et al. [10] reported significant increases in stripe rust severities between 2001 and 2010 in Central and West Asia. Five devastating stripe rust epidemics have occurred in the Central Asian region since 1999 [11], and the outbreaks were severe, particularly in Uzbekistan [11], Turkey [2], and Iran [12,13]. In 2009 and 2010, severe outbreaks occurred across Central and West Asia and North Africa, suggesting that the disease needs attention at the international level [14].

Given the expanding geographical extent and increased production losses associated with the disease, stripe rust is now the most damaging of all the cereal rusts $[2,7-9,15,16]$. Currently, most of the world's wheat-producing areas are vulnerable to stripe rust due to the widespread of virulent and aggressive races of Pst and lack of adequate resistance in wheat cultivars, and the disease causes an annual global loss of over 5 million tons 
of wheat with an estimated market value of $\$ 1$ billion $[2,9,17]$. Recent changes in the spread of the disease into nontraditional, warmer, and dryer areas suggest a wider range of adaption in the pathogen $[17,18]$. Changes in cropping systems and climates have been implicated with the recent emergence of stripe rust $[9,19]$. Stem rust continues to be a potentially devastating disease in wheat and other cereals [20,21]. After years of successful management, the re-emergence of stem rust in Africa and Europe is now an increasing threat to global food security $[6,22,23]$. Potential annual stem-rust losses have been previously estimated from $\$ 7.6$ to $\$ 53.7$ billion globally [17].

Both the stripe rust and stem rust pathogens are macrocyclic, heteroecious fungi with a complete lifecycle consisting of five spore stages. They both have wheat and other cereal crops as their primary hosts and grasses as auxiliary hosts for infection by urediniospores and aeciospores and for producing teliospores and basidiospores. Barberry (Berberis spp.) and mahonia (Mahonia spp.) serve as their alternate hosts for infection by basidiospores and production of pycniospores and aeciospores [24-28]. Several studies on molecular characterization of Pst populations using uredinial samples from wheat suggested sexual recombination occurring in some Asian countries such as China, Nepal, Pakistan, and Turkey [26,29-31]. So far, natural infection of barberry by Pst has only been found at low frequencies in China [32,33]. However, in Europe and North America, barberry plants have not been found infected by Pst but heavily infected by Pgt $[27,28,34]$. In the US Pacific Northwest, $P g t$ basidiospores can infect barberry providing aeciospores to infect and cause stem rust epidemic in wheat and barley. However, Pst cannot infect barberry due to teliospore degradation and unmatched barberry phenology $[27,28]$. Thus, weather factors appear to play an important role in making a difference in barberry infection by the two pathogens. Occurrence of rusts in wheat, other cereal crops, and grasses, and the presence of barberry plants across different geographical regions, especially in Asia and Europe, are well known $[24,26,29,35]$. The role of barberry for stem rust epidemics has been established for a long time. However, the importance of barberry species as alternate hosts for Pst and possible locations or barberry habitats serving for sexual reproduction and their role in disease recurrence are yet to be determined.

Epidemics of rusts are highly dependent upon weather conditions and cropping systems $[7,36]$. Weather conditions not only affect survival, infection, growth, and asexual reproduction, but also influence different stages throughout the complete sexual cycle, especially teliospore survival, germination, and basidiospore infection on barberry $[26,27,37]$. However, synchronization between the susceptible stage of alternate hosts and viable teliospores, together with favorable weather conditions, is vital for infection on alternate hosts by basidiospores and subsequent infection on cereals by aeciospores and urediniospores [26,27]. Although the susceptibility of a large number of Berberis species has been proven under controlled conditions, natural infection is dependent on several additional factors [26,27]. Firstly, teliospores must germinate at the time when susceptible tissue of alternate hosts is present and must encounter germinating basidiospores under favorable weather conditions. Secondly, susceptible wheat plants must be available within the distance of aeciospore dispersal during the time of aecial formation on alternate hosts. Thirdly, weather conditions must be suitable for the infection on cereals by aeciospores. Therefore, prediction or assessment of basidiospore infection on barberry based on weather conditions is vital to determine the role of alternate hosts in rust epidemics. However, most studies so far have been focused on urediniospore infection without a connection to infection on barberry. For prediction of basidiospore infection, in addition to optimum temperatures, a long duration of leaf wetness $(32 \mathrm{~h}$ ) is an important criterion for Pst to infect barberry [27].

The threshold temperatures for both Pst and Pgt infection and survival are known [7,36,38-44]. For Pst infection on barberry, a minimum of $32 \mathrm{~h}$ leaf wetness under the optimum temperature around $10^{\circ} \mathrm{C}$ is required for the process of teliospore germination, basidiospore production and germination, and germ tube penetration of barberry leaves [27]. Hourly leaf wetness or a high relative humidity $(\mathrm{RH}>95 \%)$ period is an important input for the estimation of infection risk dynamics of rusts [36]. Mechanistic models 
have been used to study plant distributions [45] and the effects of temperature and leaf wetness on infection as a measure of favorable weather [46-49]. Micro-meteorologically, leaf wetness or high RH periods can be estimated from daily minimum and maximum temperatures and rainfall [47]. Therefore, the rust favorable weather index as an indicator of barberry infection in a specific location or a large-scale region can be assessed since worldwide geospatial weather databases are available.

Infection risk, as a function of temperature and leaf wetness period, is variable in time and space. It is a primary determinant for occurrence and distribution patterns of plant diseases, particularly for rusts. Models or frameworks for assessing infection risks are vital to improve quantitative understanding of large-scale disease dynamics required for the development of strategies, management decisions, research priorities, and the analysis of future scenarios $[17,46]$. For infection risk assessment, ecological niche models or species distribution models are used to predict disease epidemics in various regions [17,21,50-52]. The NAPPFAST internet system has been used for weather-based disease prediction in both time and space [46]. For real-time monitoring of stem rust across wheat-growing regions, a mechanistic modeling framework has been used to provide risk assessments based on the growing season, meteorological suitability for infection, and aerial transport of infectious spores [4,5]. Model assumptions based only on temperature thresholds may be valid for the prediction of urediniospore infection where even a short period of leaf wetness (above $2 \mathrm{~h}$ ) is enough for the start of infection.

Assessment of infection risk in terms of environmental suitability in possible barberry habitats is necessary for global survey and rust monitoring. With the long history of wheat rusts in Asian and European countries, assessment of environmental suitability for barberry infection for these countries may improve the understanding of rust epidemiology. This can be accomplished by the calculation of a favorable weather index, as a measure of infection risk, especially for the regions where rust epidemics have been known for a long time. The assessment of environmental suitability for basidiospore infection in the presence of barberry is likely to give insights into the role of alternate hosts in rust epidemiology at regional and global scales, which is of great interest for global rust management. The objective of the present study was to assess the suitability and potential infection risk of both Pst and Pgt on barberry in Asia and the bordering Southeastern European regions using available geospatial meteorological data.

Assessment of environmental suitability for basidiospore infection in 607 locations in these regions was performed based on a rust infection index and a barberry growth index. The infection index as a suitability score and the barberry favorable growth index (thermal times) as an indicator of possible barberry habitats were combined to indicate potential infection risk for comparison among the different regions.

\section{Results}

\subsection{Stripe Rust Infection Suitability}

The infection suitability for Pst was estimated as normalized monthly infection index (MINF), and the values for all 607 sites are provided in Table S1 and the numbers and percentages of locations with different scores for the five regions are given in Table S2. The majority locations in East Asia (EA) and Central Asia (CA) had relatively low MINF values compared with locations in Northwest Asia (NWA) and bordering Southeast European countries (SEC) (Figure 1a). The median values of MINF in EA and CA were very similar, which were slightly higher than that of NWA but lower than that of SEC (Figure 1a). However, the relatively large upper whiskers in CA and NWA compared with the shorter whisker in EA indicated the existence of locations of higher MINF values in CA and NWA than in EA. However, there was one location (Mazraat Matariyet Jbaa, Lebanon) with a high MINF value; countries in SWA had the lowest MINF values. In contrast, SEC had the highest MINF values. 

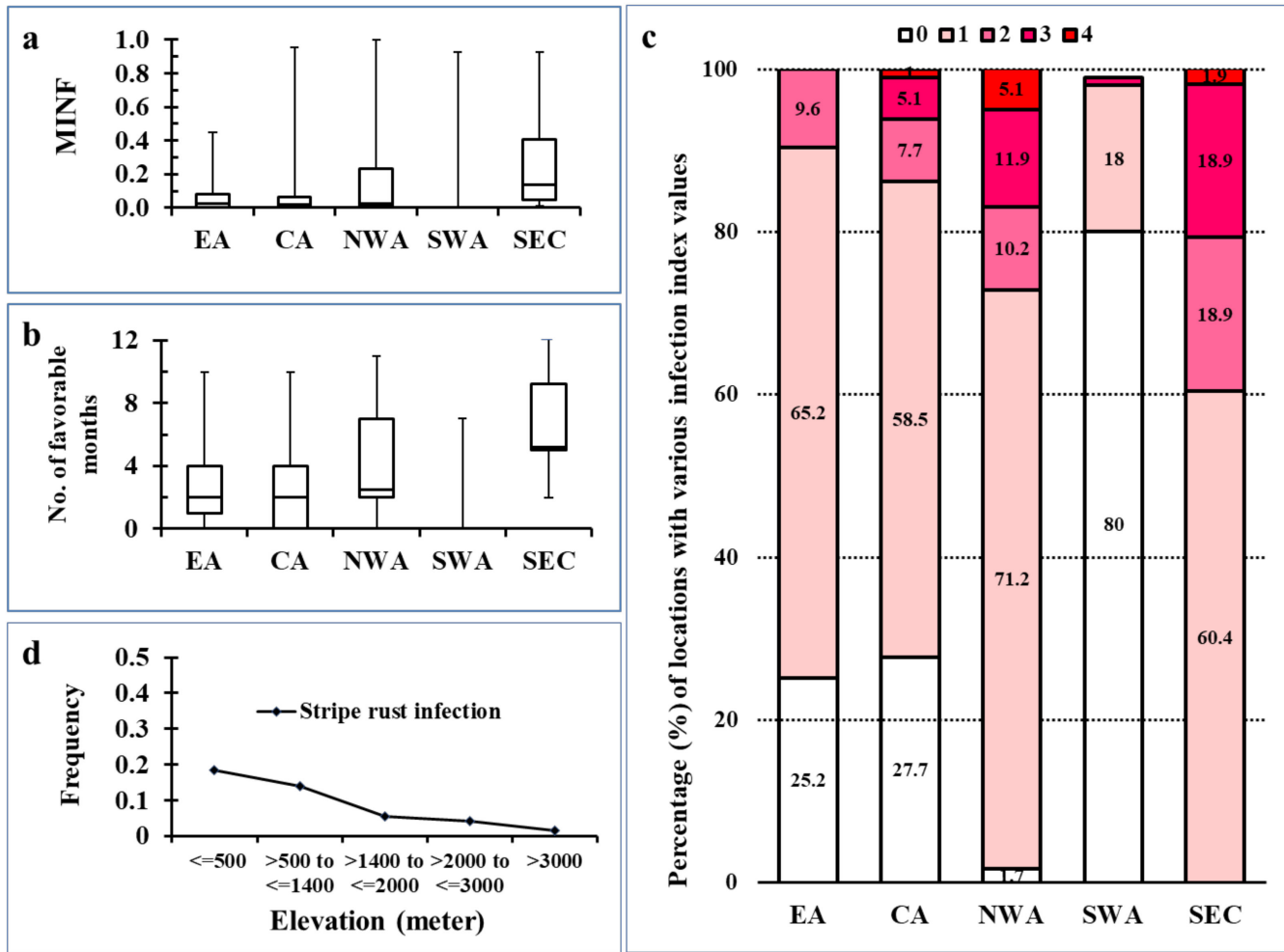

Figure 1. Normalized monthly infection index (MINF), Fav-month, and environmental suitability scores for the stripe rust pathogen (Puccinia striiformis $\mathrm{f}$. sp. tritici) infection on barberry in Asian and adjacent Southeastern European regions. (a): boxplot for MINF values; (b): boxplot for numbers of favorable months; (c): frequencies of locations in different elevation intervals; and (d): percentages of locations with suitability scores in various regions. EA = East Asia; CA = Central Asia; NWA = Northwest Asia; SWA = Southwest Asia; and SEC $=$ Southeast European Countries. Suitability scores: $0=$ no; $1=$ low; $2=$ moderate; $3=$ high; and $4=$ very high.

The stripe rust favorable periods measured as Fav-month (MINF $>0$ ) were about 2 to 4 months in EA (particularly in China, Nepal, and Bhutan) and CA (Azerbaijan, Iran, Russia, and Uzbekistan) and 2 to 7 months in NWA, indicated by the upper quartile ranges (Figure $1 \mathrm{~b}$ ). The maximum Fav-month values were up to 10 months in EA and CA and even up to 11 months in NWA (especially Turkey and Georgia). The absence or shorter lower whisker in EA and CA suggested that $25 \%$ of the locations had no or short periods favorable for Pst to infect barberry. The SEC region had the highest number of locations with high Fav-month values as indicated by the higher position of the box plot.

Few locations in EA (particularly in China, Nepal, and Bhutan) and several locations in CA (Azerbaijan, Iran, Russia, and Uzbekistan), but most of the locations in NWA (Turkey and Georgia) and almost all locations in SEC were noted with high infection index values (MINF > 0.3) along with high Fav-month values (7-11) (Table S1). Favorable periods for these locations were observed to occur between August to the next June, covering both wheat and barberry growth. The regions in SEC showed favorable conditions almost all year long, except in July and August. Twenty-four locations were noted to have favorable periods, and they were mostly located in the hilly zones around the Caspian Sea and Black Sea.

Infection suitability scores estimated (as the product of the MINF and Fav-month values and the scores assigned) indicated that the proportion of locations with scores suitable for infection increased from the east to west (Figure 1c). In EA, 74.8\% of the locations had low to moderate scores (1-2) as compared with CA, with $66.2 \%$ of the locations having low to moderate scores (1-2) and $6.1 \%$ having high sores (3-4). The proportions of locations with nonzero infection index values were $98.3 \%$ and $100 \%$ in NWA 
and SEC, respectively. These data indicate that the probability of finding barberry infected by Pst is higher in NWA and SEC than EA and CA (Table S2).

The environmental suitability index was noted to increase with latitude and decrease with longitude (Table S1). Association of infection suitability with latitude and longitude indicated their dependence on locations as the likelihood log ratio and Fisher's exact test were significant $(p<0.05)$. However, the dependence level was weak (low Phi and Cramer's $\mathrm{V}$ values), indicating no strong relationship between infection risk and location feature. The association pattern in terms of latitude and longitude indicated environmental suitability for rust infection is in specific locations represented by a spatial aggregation more towards the NWA region. The proportion of locations with infection suitability was noted to be associated with elevation. The proportion of locations was higher in the range of 500 to $1400 \mathrm{~m}$ above sea level than in the locations of higher elevation, and the proportion decreased with increasing elevation (Figure 1d). Only few locations with elevations of $3000 \mathrm{~m}$ or above were noted to have suitable conditions for Pst to infect barberry.

\subsection{Stem Rust Infection Suitability}

The infection suitability for Pgt was estimated as MINF for 607 locations are given in Supplementary Table S1, and the numbers and percentages of locations with different scores for the five regions are summarized in Table S3. The Pgt MINF values with a mean of 0.11 across all 607 sites were significantly higher $(p<0.0001)$ than the mean of 0.09 for Pst (Table S1). Distinctly higher Pgt MINF values in EA were noted as the median position was higher than those in CA and NWA (Figure 2a). The environmental suitability for $P g t$ as measured by MINF was highest in SEC but lowest in SWA among the five regions. The majority of the locations in SEC had high MINF values as indicated by the elevated level of quartile and median positions.

The favorable period for rust infection estimated as Fav-month for each location is also given in Table S1. Twenty-four locations were noted to have favorable periods and are mostly in the hilly zones surrounding the Caspian Sea and the Black Sea. The Fav-month values in all these regions occurred between August to following June, covering the growth season for both wheat and barberry. SEC showed favorable conditions almost all year long except July and August. The mean Fav-month value of Pgt (0.33) across all 607 locations was significantly higher $(p<0.0001)$ than that of Pst $(0.25)$, indicating that the weather conditions in the studied regions are more favorable for Pgt than for Pst to infect barberry. The median value of Fav-month for SEC was the highest, followed by NWA and EA, and the lowest for SWA (Figure 2b), similar to the general pattern of Pst (Figure 1b).

Locations with high infection index values (MINF $>0.3$ ) along with high Fav-month values (7-11) were noted in EA (particularly in Bangladesh, Bhutan, China, and Nepal) and CA (Azerbaijan, Iran, Russia, and Uzbekistan), the majority in NWA (Turkey and Georgia), several in SWA, and almost all in SEC (Table S1).

The Pgt infection suitability pattern was more or less similar to that of Pst. Notably, 72.3 and $75.6 \%$ of the locations in EA and CA, respectively, had any infection risks but the proportion of locations with high risks was greater in CA (Figure 2c; Table S3). The NWA and SEC regions had much higher infection risks, with 98.4 and $100 \%$ of their locations, respectively, having an infection suitability index of at least L (low score). These data indicate that the probability of finding locations favorable for Pgt infection is higher in SEC and NWA than in EA and CA and is the lowest in SWA (24\%) (Figure 2c; Table S3). 


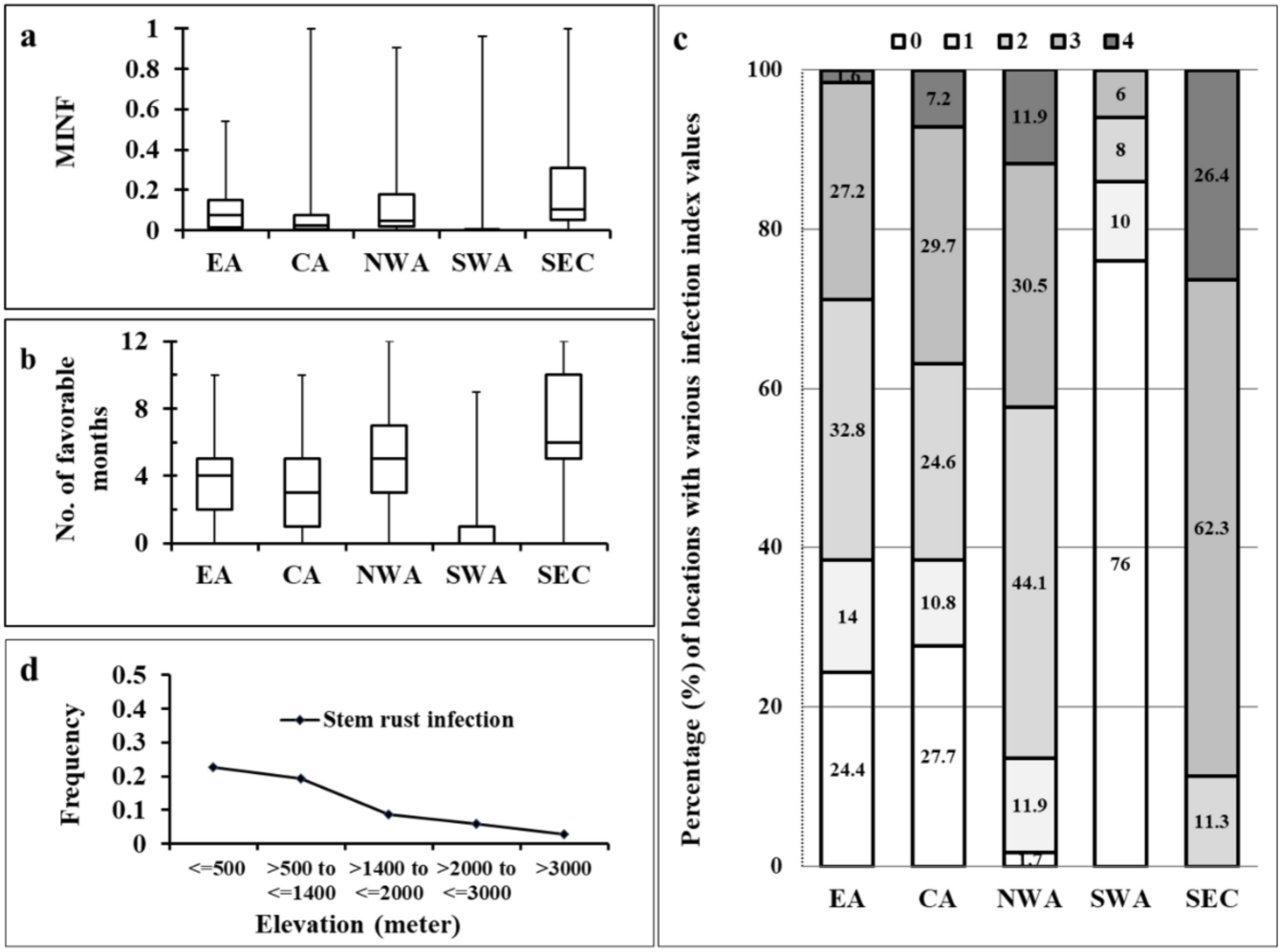

Figure 2. Normalized monthly infection index (MINF), Fav-month, and environmental suitability scores for the stem rust pathogen (Puccinia graminis $\mathrm{f}$. sp. tritici) infection on barberry in Asian and adjacent Southeastern European regions. (a): boxplot for the MINF values; (b): boxplot for the numbers of favorable months; (c): frequencies of locations in different elevation intervals; and (d): percentages of locations with suitability scores in various regions. EA = East Asia; CA = Central Asia; NWA = Northwest Asia; SWA = Southwest Asia; and SEC = Southeast European Countries. Suitability scores: $0=$ no; $1=$ low; $2=$ moderate; 3 = high; and $4=$ very high.

The Pgt infection index was also observed to be associated with elevation, latitude, and longitude as indicated by the significant likelihood log ratio and Fisher's exact test $(p<0.05)$. However, the association level was weak (low Phi and Cramer's V values), indicating some but not strong relationship between rust infection and location features. Similar to Pst, the proportion of locations with infection suitability of at least L was noted to be associated with elevation as the frequency of locations was higher in locations of 500 to $1400 \mathrm{~m}$ above the sea level, and the proportion decreased with increasing elevation (Figure 2d). Fewer locations with elevations of $3000 \mathrm{~m}$ or higher were noted to be suitable for Pgt. It was noted that most of the locations suitable for Pgt were also suitable for Pst, but this was not always the case.

\subsection{Barberry Growth Index}

Barberry growth was measured in terms of monthly thermal index (NHTT). The NHTT value, Fav-month, favorable growth index, growth suitability score, and the number of favorable months for each of the 607 locations are provided in Table S1, and the number and percentage of locations with various growth suitability scores for each of the five regions are summarized in Table S4. The NHTT values were similar in EA and CA as indicated by the close median values with wider variations among locations (Figure 3a). The NWA and SEC regions had higher NHTT values than the other regions, especially indicated by their median values. The SWA region had the lowest NHTT value, indicating less suitable conditions for barberry growth. The majority of the locations in all five regions had a period of more than 7 months favorable for barberry growth (Figure 3b). 

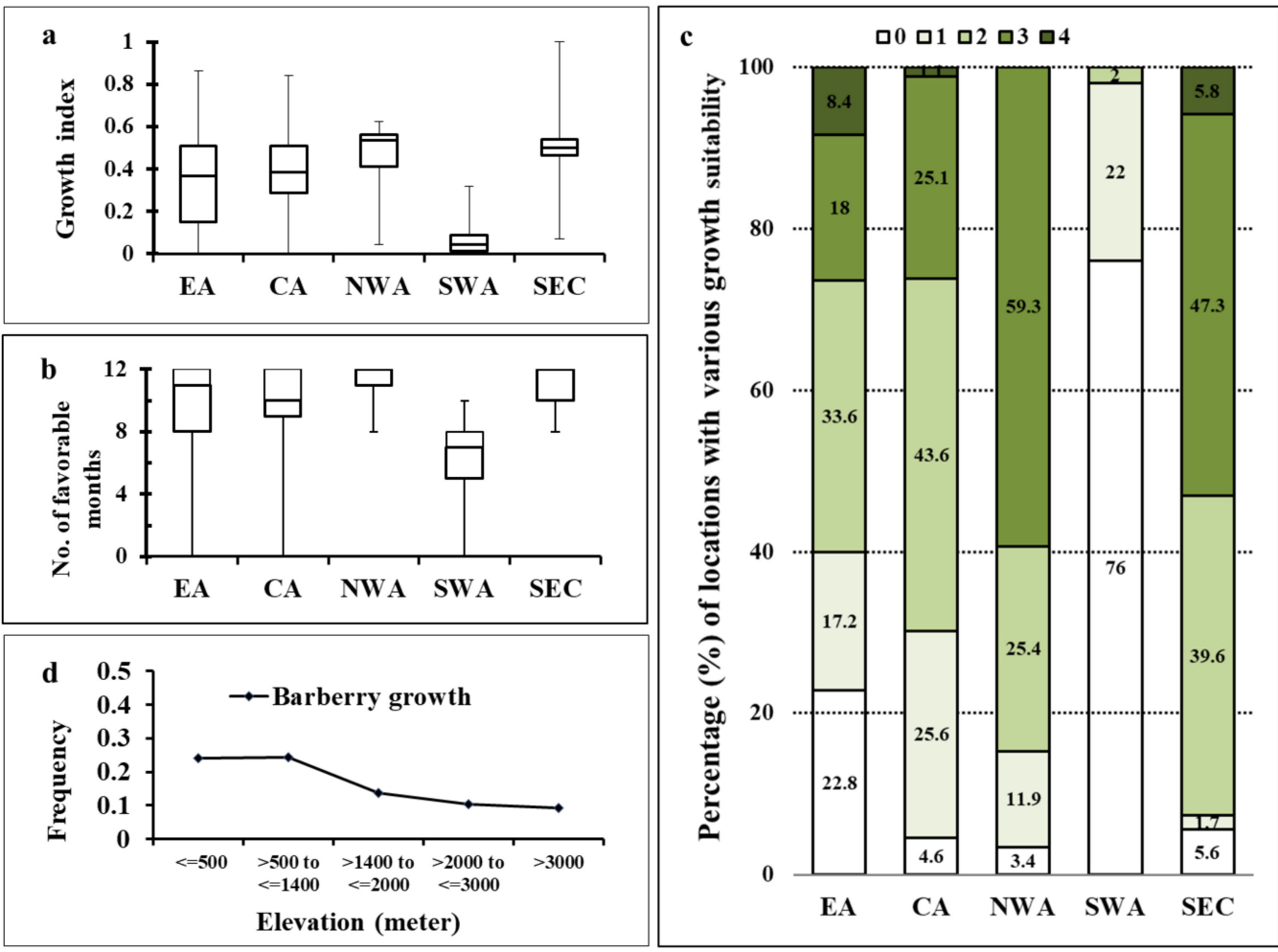

Figure 3. Normalized hourly thermal times (NHTT), Fav-month, and environmental suitability scores for barberry (Berberis vulgaris) in Asian and adjacent Southeastern European regions. (a): boxplot for NHTT values; (b): boxplot for numbers of favorable months; (c): frequencies of locations in different elevation class interval; and (d): percentages of locations with growth suitability scores in various regions. $\mathrm{EA}=$ East Asia; $\mathrm{CA}=$ Central Asia; NWA = Northwest Asia; SWA = Southwest Asia; and SEC $=$ Southeast European Countries. Suitability scores: $0=$ no or least favorable; $1=$ low; 2 = moderate; 3 = high; and 4 = very high growth.

Suitability for barberry growth was estimated with scores assigned based on the product of NHTT and Fav-month. Most locations in all regions were found to be mostly favorable for barberry growth, except SWA where only $24 \%$ of locations had low to moderate suitability (Figure 3c, Table S4). In EA and CA, about 50 to $68 \%$ of the locations had low to moderate suitability, and $26 \%$ with high to very high suitability scores. About 52 to $59 \%$ of the locations in NWA and SEC had high to very high suitability scores. Countries with reported barberry growth included Bhutan, China, Nepal, India, and Pakistan in EA; Afghanistan, Azerbaijan, Iran, Kyrgyzstan, Russia, Tajikistan in CA; Armenia and Turkey in NWA; and Bulgaria, Croatia, Greece, Italy, Montenegro, Slovenia, Romania, and Ukraine in SEC based on various sources.

The association of barberry growth index with elevation was significant $(p<0.05)$. The proportion of locations (frequency) with conditions suitable for barberry growth was the highest in the elevation range $\leq 1400 \mathrm{~m}$, dropped quickly in the range between 1400 and $2000 \mathrm{~m}$, and continually decreased in locations of $>3000 \mathrm{~m}$ (Figure 3d).

\subsection{Sensitivity Analysis of Parameter $b$}

Infection index (INF) was sensitive to parameter $b$, the rate of change in infection index with $\mathrm{h}(\mathrm{RH} \mathrm{h} \geq 95 \%)$. The INF values were relatively stabilized between 0.1 and 0.15 for both Pst and Pgt (Figure S1). Parameter estimation for the $b$ value using 0.117 reported for leaf rust was found to be appropriate for assessing infection index values and suitability comparison among locations. The number of locations or their frequency under a given infection suitability score (particularly for ' 0 or no risk') varied when the upper limit 0.01 was fixed. Similarly, the number of locations for barberry growth was observed to differ in 
magnitude, particularly for the no suitability ' 0 ' category when the upper limit was fixed at 0.01 . The infection index range for other scores did not change much as far as the number of locations in different categories was concerned.

\subsection{Comparison of Environmental Suitability Patterns Predicted from the Framework and Dymex Model}

Environmental suitability in terms of rust infection index predicted by the modeling framework indicated a fair degree of correspondence with the growth index predicted by the Dymex model as far as the rust distribution was concerned. The relative levels of Pst risk predicted by the framework for western China, the Indo-Pakistan-Nepal-Bhutan subcontinent CA, NWA, and SEC (Figure S2a) were consistent with the predictions using the Dymex model (Figure S3a). However, the predictions by the two models appeared different for eastern China and CA. The Pgt risk patterns predicted by the framework model and the Dymex model were similar throughout the regions studied (Figures S2b and S3b). The predictions for barberry growth by the two models were similar for most of China, NWA, and SEC, but quite different for part of EA and CA (Figures S2c and S3c). The Dymex output indicated a sparse distribution of barberry across EA and CA, but the framework model predicted locations with highly favorable conditions for barberry growth in EA (particularly in the Indo-Nepal-Bhutan-southwestern China region) and CA. Quantitative comparison of rust infection suitability for selected locations in the US Pacific Northwest and western China indicated a moderate to a substantial level of correspondence for both Pst and Pgt $(k=0.50-0.68)$, while for barberry growth the correspondence was slightly lower, but still fair $(k=0.40-0.50)$ (Table S5).

\subsection{Potential Risk for Pst and Pgt Infection on Barberry}

Potential risks of Pst and Pgt were determined for each location considering the suitability for infection index and the barberry growth index (Table S1). For Pst infection, potential risk (with scores 1 to 4 ) was observed for 254 (42\%) locations out of the 607 locations studied, including 103 (41\%) in EA, 82 (42\%) in CA, 24 (41\%) in NWA, 1 (2\%) in SWA, and $46 \%$ in SEC (Table 1). These locations were distributed across 26 countries, including 15 countries (Bhutan, China, and Nepal in EA; Azerbaijan, Kazakhstan, and Russia in CA; Georgia in NWA; Albania, Croatia, Greece, Italy, Montenegro, Romania, Slovenia, and Ukraine in SEC) with more than half of the locations having various levels of potential risk. However, no locations in EA and SWA had high risks (scores 3 and 4). Among the 18 locations with high risks, 7 were located in CA (2 in Azerbaijan, 2 in Iran, and 3 in southern Russia), 6 in NWA (Turkey), and 5 in SEC (1 in Albania, 2 in Croatia, 1 in Italy, and 1 in Montenegro). In general, SEC had the highest risk score (1.30), followed by NWA (0.75), CA (0.58), and EA (0.50), and the lowest was in SWA (0.02) when considering both the number of locations and the level of risks.

For Pgt infection, 308 (51\%) out of the 607 locations in 28 countries were found to have various levels of potential risks (Table 2). Seventeen of the 28 countries had more than half of the locations with potential risks. Of the 308 locations, 10 had high-risk scores (3 and 4), including 1 in China, 2 in Azerbaijan, 1 in Russia, 1 in Albania, 1 in Bulgaria, 2 in Croatia, 1 in Italy, and 1 in Montenegro. When considering both the number of locations and the level of risks, SEC had the highest risk score (1.34), followed by NWA (0.76), EA (0.64), and CA (0.58), and again the least in SWA (0.08). 
Table 1. Locations of potential infection risk from Puccinia striiformis f. sp. tritici in Asian and Southeast European countries.

\begin{tabular}{|c|c|c|c|c|c|c|c|}
\hline \multirow{2}{*}{ Region (No. of Locations) } & \multicolumn{5}{|c|}{ No. of Locations with Risk Scores } & \multicolumn{2}{|c|}{ Potential Risk } \\
\hline & 1 & 2 & 3 & 4 & Total & Proportion $^{a}$ & Risk Score ${ }^{b}$ \\
\hline \multicolumn{8}{|c|}{ East Asia } \\
\hline Bhutan (9) & 5 & & & & 5 & 0.56 & 0.56 \\
\hline China (142) & 51 & 22 & & & 73 & 0.51 & 0.67 \\
\hline India (45) & 11 & & & & 11 & 0.24 & 0.24 \\
\hline Nepal (15) & 10 & & & & 10 & 0.67 & 0.67 \\
\hline Pakistan (16) & 4 & & & & 4 & 0.25 & 0.25 \\
\hline Regional total (250) & 81 & 22 & & & 103 & 0.41 & 0.50 \\
\hline \multicolumn{8}{|c|}{ Central Asia } \\
\hline Afghanistan (20) & 1 & & & & 1 & 0.05 & 0.05 \\
\hline Azerbaijan (16) & 6 & 3 & 1 & 1 & 11 & 0.69 & 1.19 \\
\hline Iran (58) & 11 & 10 & 2 & & 23 & 0.40 & 0.64 \\
\hline Kazakhstan (18) & 9 & 1 & & & 10 & 0.56 & 0.61 \\
\hline Kyrgyzstan (14) & 2 & & & & 2 & 0.14 & 0.14 \\
\hline Russia (23) & 16 & 1 & 3 & & 20 & 0.87 & 1.17 \\
\hline Tajikistan (13) & 3 & & & & 3 & 0.23 & 0.23 \\
\hline Turkmenistan (20) & 6 & & & & 6 & 0.30 & 0.30 \\
\hline Uzbekistan (13) & 4 & 2 & & & 6 & 0.46 & 0.62 \\
\hline Regional total (195) & 58 & 17 & 6 & 1 & 82 & 0.42 & 0.58 \\
\hline \multicolumn{8}{|c|}{ Northwest Asia } \\
\hline Georgia (9) & 5 & 2 & & & 7 & 0.78 & 1.00 \\
\hline Turkey (40) & 5 & 6 & 6 & & 17 & 0.43 & 0.88 \\
\hline Regional total (59) & 10 & 8 & 6 & & 24 & 0.41 & 0.75 \\
\hline \multicolumn{8}{|c|}{ Southwest Asia } \\
\hline Syria (3) & 1 & & & & 1 & 0.33 & 0.33 \\
\hline Regional total (50) & 1 & & & & 1 & 0.02 & 0.02 \\
\hline \multicolumn{8}{|c|}{ Southeast European countries } \\
\hline Albania (1) & & & 1 & & 1 & 1.00 & 3.00 \\
\hline Bulgaria (15) & 4 & 2 & & & 6 & 0.40 & 0.53 \\
\hline Croatia (2) & & & 1 & 1 & 2 & 1.00 & 3.50 \\
\hline Greece (4) & 1 & 3 & & & 4 & 1.00 & 1.50 \\
\hline Italy (5) & 1 & 3 & 1 & & 5 & 1.00 & 2.00 \\
\hline Montenegro (1) & & & 1 & & 1 & 1.00 & 3.00 \\
\hline Romania (11) & 10 & 1 & & & 11 & 1.00 & 1.09 \\
\hline Slovenia (1) & & 1 & & & 1 & 1.00 & 2.00 \\
\hline Ukraine (15) & 10 & 4 & & & 14 & 0.93 & 1.20 \\
\hline Regional total (53) & 26 & 14 & 4 & 1 & 45 & 0.85 & 1.30 \\
\hline
\end{tabular}

${ }^{a}$ Total number of locations in all risk categories (1-4) divided by the total number of locations. ${ }^{\mathrm{b}}$ Sum of potential risk scores (no. location $\times$ potential risk score) divided by the total number of locations.

Table 2. Locations of potential infection risk from Puccinia graminis f. sp. tritici in Asian and Southeast European countries.

\begin{tabular}{|c|c|c|c|c|c|c|c|}
\hline \multirow{2}{*}{ Region (No. of Locations) } & \multicolumn{5}{|c|}{ No. of Locations with Risk Scores } & \multicolumn{2}{|c|}{ Potential Risk } \\
\hline & 1 & 2 & 3 & 4 & Total & Proportion $^{a}$ & Risk Score $^{b}$ \\
\hline \multicolumn{8}{|c|}{ East Asia } \\
\hline Bhutan (9) & 3 & 2 & & & 5 & 0.56 & 0.78 \\
\hline China (142) & 77 & 23 & 1 & & 101 & 0.71 & 0.89 \\
\hline India (45) & 13 & & & & 13 & 0.29 & 0.29 \\
\hline Nepal (15) & 9 & & & & 9 & 0.60 & 0.60 \\
\hline Pakistan (16) & 5 & & & & 5 & 0.31 & 0.31 \\
\hline
\end{tabular}

${ }^{a}$ Total number of locations in all risk categories (1-4) divided by the total number of locations. ${ }^{\mathrm{b}}$ Sum of potential risk scores (no. location

$\times$ potential risk score) divided by the total number of locations. 
Table 2. Cont.

\begin{tabular}{|c|c|c|c|c|c|c|c|}
\hline \multirow{2}{*}{ Region (No. of Locations) } & \multicolumn{5}{|c|}{ No. of Locations with Risk Scores } & \multicolumn{2}{|c|}{ Potential Risk } \\
\hline & 1 & 2 & 3 & 4 & Total & Proportion $^{a}$ & Risk Score $^{b}$ \\
\hline Regional total (250) & 107 & 25 & 1 & & 133 & 0.53 & 0.64 \\
\hline \multicolumn{8}{|c|}{ Central Asia } \\
\hline Afghanistan (20) & 1 & & & & 1 & 0.05 & 0.05 \\
\hline Azerbaijan (16) & 9 & 4 & 2 & & 15 & 0.94 & 1.44 \\
\hline Iran (58) & 16 & 9 & & & 25 & 0.43 & 0.64 \\
\hline Kazakhstan (18) & 15 & & & & 15 & 0.83 & 0.83 \\
\hline Kyrgyzstan (14) & 1 & & & & 1 & 0.07 & 0.07 \\
\hline Russia (23) & 19 & 3 & 1 & & 23 & 1.00 & 1.22 \\
\hline Tajikistan (13) & 1 & & & & 1 & 0.08 & 0.08 \\
\hline Turkmenistan (20) & 2 & 1 & & & 3 & 0.15 & 0.20 \\
\hline Uzbekistan (13) & 5 & 1 & & & 6 & 0.46 & 0.54 \\
\hline Regional total (195) & 68 & 18 & 3 & & 89 & 0.46 & 0.58 \\
\hline \multicolumn{8}{|c|}{ Northwest Asia } \\
\hline Armenia (10) & 9 & & & & 9 & 0.90 & 0.90 \\
\hline Georgia (9) & 7 & 1 & & & 8 & 0.89 & 1.00 \\
\hline Turkey (40) & 9 & 9 & & & 18 & 0.45 & 0.68 \\
\hline Regional total (59) & 25 & 10 & & & 35 & 0.59 & 0.76 \\
\hline \multicolumn{8}{|c|}{ Southwest Asia } \\
\hline Iraq (5) & 1 & & & & 1 & 0.20 & 0.20 \\
\hline Syria (3) & 3 & & & & 3 & 1.00 & 1.00 \\
\hline Regional total (50) & 4 & & & & 4 & 0.08 & 0.08 \\
\hline \multicolumn{8}{|c|}{ Southeast European countries } \\
\hline Albania (1) & & & 1 & & 1 & 1.00 & 3.00 \\
\hline Bulgaria (15) & 6 & 2 & 1 & & 9 & 0.60 & 0.87 \\
\hline Croatia (2) & & & 1 & 1 & 2 & 1.00 & 3.50 \\
\hline Greece (4) & & 2 & & & 2 & 0.50 & 1.00 \\
\hline Italy (5) & & 4 & 1 & & 5 & 1.00 & 2.20 \\
\hline Montenegro (1) & & & 1 & & 1 & 1.00 & 3.00 \\
\hline Romania (11) & 11 & & & & 11 & 1.00 & 1.00 \\
\hline Slovenia (1) & & 1 & & & 1 & 1.00 & 2.00 \\
\hline Ukraine (15) & 11 & 3 & & & 14 & 0.93 & 1.13 \\
\hline Regional total (53) & 28 & 12 & 5 & 1 & 46 & 0.87 & 1.34 \\
\hline
\end{tabular}

${ }^{a}$ Total number of locations in all risk categories (1-4) divided by the total number of locations. ${ }^{\mathrm{b}}$ Sum of potential risk scores (no. location $\times$ potential risk score) divided by the total number of locations.

The distribution of potential risks of infection on barberry by Pst is illustrated in Figure 4 and that by Pgt in Figure 5. The EA region was less favorable for Pst than the CA and NWA regions. However, for Pgt, the EA region was more favorable than the CA region. The SEC region appeared to be most favorable for both Pst and Pgt, and the SWA region the least favorable for both the rust fungi for infection on barberry. The majority of locations favorable for Pst were also favorable for Pgt, but not always. As the maps indicated, areas in southwestern China and contiguous hilly regions of Indo-Pak-Nepal-Bhutan in EA, the Iran-Southern Russia-Kazakhstan-Turkmenistan-Uzbekistan region in CA, the areas surrounding the Black Sea and Caspian Sea (including Azerbaijan, Georgia, and Turkey) in NWA, and the adjacent SEC should be ground searched for monitoring barberry infection by Pst and/or Pgt. 


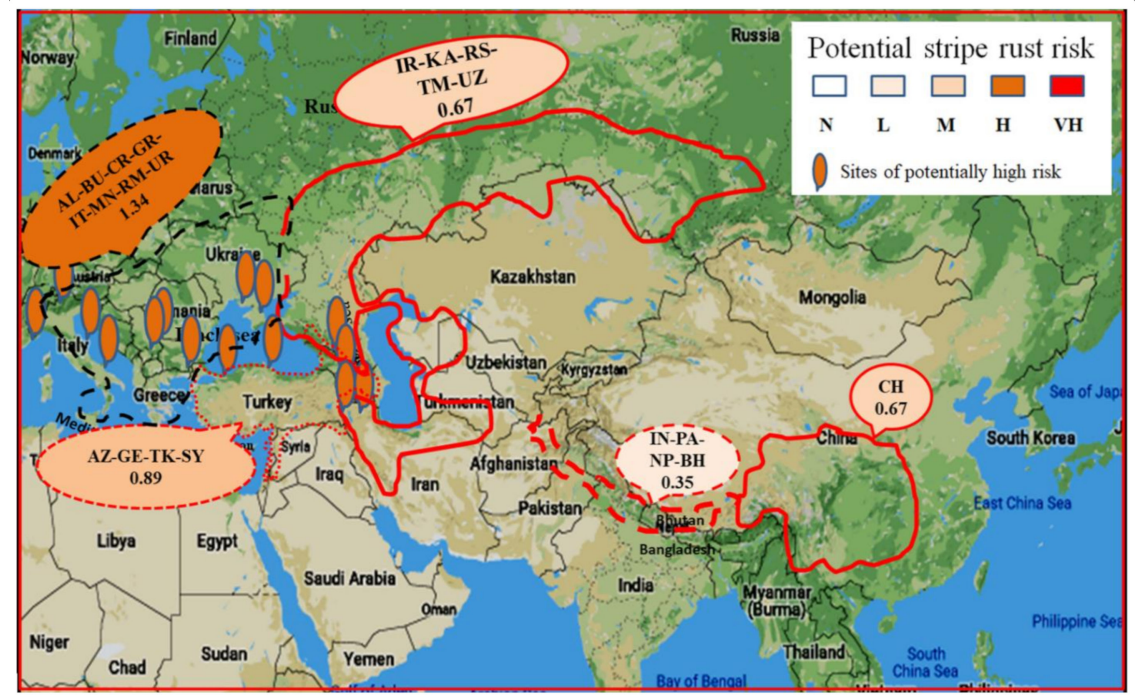

Figure 4. Areas of potential infection risks for the stripe rust pathogen (Puccinia striiformis f. sp. tritici) in Asia including China, hilly regions of Indo-Pak-Nepal-Bhutan (IN-PA-NP-BH), Central Asia (IR-KA-RS-TM-UZ), and West Asia surrounding Black Sea and Caspian Sea (GE-AZ-TK). $\mathrm{AZ}=$ Azerbaijan, $\mathrm{BH}=$ Bhutan, $\mathrm{CH}=$ China, $\mathrm{IN}=$ India, IR = Iran, KA = Kazakhstan, NP = Nepal, $\mathrm{PA}=$ Pakistan, $\mathrm{RS}=$ Russia, $\mathrm{TM}=$ Turkmenistan, and UZ = Uzbekistan .

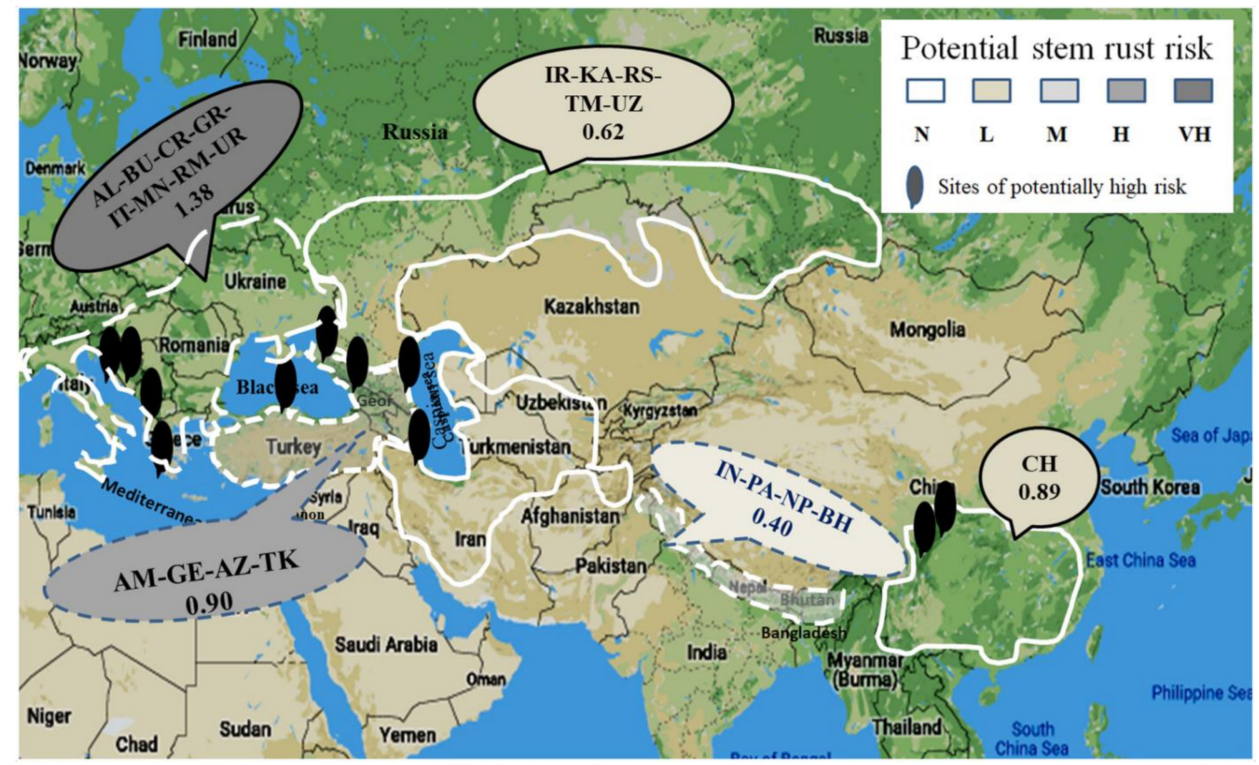

Figure 5. Areas of potential infection risks for the stem rust pathogen (Puccinia graminis f. sp. tritici) in Asia, including China, hilly regions of Indo-Pak-Nepal-Bhutan (IN-PA-NP-BH), Central Asia (IR-KA-RS-TM-UZ), and West Asia surrounding Black Sea and Caspian Sea (AM-GE-AZ-TK). $\mathrm{AM}=$ Armenia, $\mathrm{AZ}=$ Azerbaijan, $\mathrm{BH}=$ Bhutan, $\mathrm{CH}=$ China, $\mathrm{IN}=$ India, $\mathrm{IR}=$ Iran, $\mathrm{KA}=$ Kazakhstan, $\mathrm{NP}=$ Nepal, $\mathrm{PA}=$ Pakistan, $\mathrm{RS}=$ Russia, $\mathrm{TM}=$ Turkmenistan, and UZ = Uzbekistan .

\section{Discussion}

Potential risks of Pst and Pgt infections in barberry were assessed for Asia and the adjoining Southeastern European countries. In general, we found comparatively low Pst risks in EA, low to high risk in CA, high to very high risk in NWA, and moderate to very high risk in SEC, and a more or less similar risk pattern for Pgt across the regions except for some different risk level increments. In EA, particularly Bhutan, China, and Nepal were noted with locations of high potential risks for Pgt compared with the relatively low risk for Pst. This is the first study of the potential risk of barberry infection by both Pst and 
Pgt in a large geographical scale covering the entire Asian region as well as the adjacent European countries.

Environmental suitability for barberry infection by Pst and Pgt is useful for the prediction of rust outbreaks and distributions, especially for regions where the uredinial stage cannot survive the hot summer and/or cold winter and aeciospores from barberry are essential to initial inocula. The modeling framework used in this study estimates infection risk for the entire process from teliospore germination, through basidiospore production and germination, to penetration of barberry leaves by germ tubes grown from basidiospores as the infection by Pst or Pgt is strongly constrained by leaf wetness or high RH hours and temperatures $[27,36,38,53]$. The assessment framework assumes the presence of viable teliospores in the nearby barberry habitats having susceptible tender leaves, stems, and berries. Prediction of rust risk is more realistic when also taking barberry growth into consideration. However, variation in rust resistance, growth stages, and phenology of Berberis species were not considered in the present study, which could be considered in future studies focusing on individual regions with clear information of Berberis species related to the issues.

The current finding was based on the estimates of favorable infection index (MINF) and period of occurrence used as a measure of infection suitability. The environmental suitability should explain at least a part of the infection process (basidiospore germination and subsequent penetration) involved in the epidemic development. Rust infection suitability and barberry favorable scores are important components to assess possible role of alternate hosts in a particular region and the global in general. Occurrence of stripe rust and stem rust on wheat, other cereals, and grasses and presence of barberry hosts in the geographical regions of the present study is well known $[26,32,40,54,55]$. Therefore, the assessment of suitability for these components is verifiable.

The mechanistic model used for estimating environmental suitability or infection index is structurally sound, and it explains the infection process coupling the effect of temperature and leaf wetness hours. Rust infection is best explained by incorporating the effects of both temperature and leaf wetness factors [36,38,46,48]. The model prediction corresponded with some real observations in the locations where barberry infection is known $[24,26]$. Therefore, the model assumptions were valid and thus reasonable to be used for assessing potential infection risk. The current model framework was workable, but its computation was intensive, particularly when daily data was used as input. Available computational tools were used to implement such prediction scheme for the assessment of leaf wetness hours and infection index. The Dymex model predicts mainly the temperature effect on infection using soil moisture in a deterministic setup. It can be useful only when risk estimation is not affected by leaf wetness hours or any moisture parameters. Such model may be useful for predicting urediniospore infection on wheat, for which even 2- or 3 -h of high RH on wheat leaves may allow urediniospore infection $[4,5,21,37]$. However, barberry infection cannot be explained without consideration of a much longer continual duration of high RH or dew formation as the duration needs to be long enough for starting with teliospore germination to basidiospore germination and penetration on barberry leaves $[27,37]$.

Sensitivity analysis of the core parameter $b$, rate of change in infection index with leaf wetness hour, was observed to be stabilized between 0.1 and 0.15 for both Pst and $P g t$. Therefore, the use of $b$-value 0.117 , which was reported for leaf rust [48], in the model for estimation of Pst and Pgt infection indices is justifiable for comparison of infection index values among locations. Potential infection risks for both Pst and Pgt in China identified in the present study complements the earlier reports of natural infections and the possibility of China being a hotspot for sexual reproduction [22,26,32,33,56]. In China, through artificial inoculation of barberry plants with germinated Pst teliospores, 28 Berberis species have been identified to be susceptible to the pathogen [32,33]. However, Pst aecia have been identified in very low frequencies collected from naturally infected plants of five species (B. aggregata, B. brachypoda, B. polyantha, B. shensiana, and B. soulieana). The 
present finding of low to moderate infection risk for Pst noted in China is consistent with low Pst aecial frequencies on barberry as previously reported [32,33]. High infection risk for Pgt in China appears to be well-founded [32]. Low infection potential in the Himalayan hills of Indo-Pak-Nepal-Bhutan reasserts the view of sexual reproduction in the area but with small likelihood. It is possible that barberry infection is occurring but remaining unnoticed due to low infection intensity. Susceptibility of the barberry species collected from Himalayan hills (the Pakistan-Gilgit area) and through artificial infection with teliospores from wheat and infection of wheat with aeciospores reaffirm the view of possible sexual reproduction [30,57]. In Nepal, stripe rust infection in wheat fields during the 2019 crop season and aecia observed on nearby barberry leaves indicated the likely infection risk of stripe rust (https: / / www.wheatrust.org, accessed on 2 October 2020). The extended Himalayan region, including India, Pakistan, Nepal, and China in EA and the countries in CA and NWA have been inferred as the regions for sexual reproduction $[2,12,17,30,58-61]$.

The high potential risks for both Pst and Pgt estimated in the present study indicate that CA NWA, and along with SEC, are the possible regions suitable for both pathogens. In CA and NWA, the large number of locations with high potential risks, particularly in Iran, Azerbaijan, Uzbekistan, southern Russia, Turkey, and Georgia, suggest existence of environmental conditions suitable for both the rust fungi. Stripe rust and stem rust on wheat commonly occur in these countries $[11,13,29,54,62,63]$. Barberry leaves with aecia were observed in Azerbaijan, Georgia, Iran, Tajikistan, Turkey, and Uzbekistan [13,20,24,64,65], indicating at least one of the rust fungi infecting barberry. The barberry suitability scores in these countries support the high potential of barberry infection. Races of Pgt with high variability to $\mathrm{Sr}$ resistance genes have been identified from aecial samples from the infected barberry plants in Kelardasht and the mountainous areas surrounding Caspian Sea, indicating that barberry species serve as alternate hosts for Pgt in these regions [13]. The large number of favorable locations in CA, NWA, and the Balkan region in southeastern Europe identified in the present study surround Caspian, Black, Aegean, and Ionian seas. Therefore, the areas along the coasts of these seas most likely satisfy the conditions for such a prolonged period of leaf wetness $(32 \mathrm{~h})$ required for Pst teliospore germination and infection. Ground surveys should be conducted in these areas to prove the hypothesis.

The similar geographical distribution patterns for stripe rust and stem rust of wheat and potential barberry infection support the view that the locations favorable for the wheat rusts are also suitable for infection on the alternate hosts. The fair level of barberry suitability noted in the present study predicates the authenticity of these locations for possible barberry infection. Our results of risk prediction based on weather conditions support previous reports as regions of perpetual risk of $P g t$ for barberry infection in the same specified locations of China and Northwestern Asian region have been predicted based on the components of the epidemic process (susceptible wheat crop, viable spore, and weather factors) $[4,5,21]$. Regions normally having rust infection in wheat crops assure availability of matured teliospores that is the first requirement for barberry infection. Potential infection risk refers to specific conditions for the production and survival of teliospores as well as barberry growth. The majority of the locations that are observed to be common for rust epidemics (urediniospore infection) as well as for rust suitability risk for basidiospore infection on alternate hosts indicate that regions favorable for large-scale urediniospore infection may be the probable regions also for basidiospores infection on barberry $[4,5,17,21]$. Therefore, the potential risks of both Pst and Pgt in the locations/regions predicted in the present study is well justifiable.

For estimating the barberry growth index, model parameterization was done based on the growth features of $B$. vulgaris [66]. Therefore, infection suitability described in the present study is with reference to $B$. vulgaris. The suitability may be extended to other species with a similar growth pattern with $B$. vulgaris but may not be applicable to species with very different growth patterns. Bhutan and China in EA and Afghanistan, Azerbaijan, Iran, Kyrgyzstan, Russia, Tajikistan, and Turkmenistan in CA were found to be most 
favorable for barberry growth throughout the year, which were consistent with previous reports [66]. Our predictions indicated that the Indo-Pak-Nepal-Bhutan-China region had better barberry growth than CA countries. However, the geographical distribution of B. vulgaris reported by the Global Biodiversity Facility (https:/ / gbif.org, accessed on 5 December 2020) shows that the Indo-China region has low growth of B. vulgaris, but high abundance is shown when all Berberis spp. are considered. This is also demonstrated by ground surveys in China, and most of the artificially tested Berberis species in China have been reported susceptible to Pst infection [32,33,67]. Different Berberis species have been reported in India but not including B. vulgaris [68]. The barberry growth predicted for different regions in the present study, together with reports in the literature, indicates the availability of susceptible alternate hosts. Therefore, the predicted low to moderate infection risk for the Indo-Pak-Nepal-Bhutan-China region may be ascribed to varying degrees of environmental suitability as well as uneven distribution of barberry both in terms of species and phenology. The rust infection risks estimated in the present study indicate weather conditions in many locations are favorable to either Pst or Pgt infections during wheat growth ([4,5]; https:/ / gbif.org, accessed on 5 December 2020).

However, the ability to infect barberry is not only dependent on environmental conditions but also dependent of the characteristics of the rust pathogen. Barberry infection in the U.S. Pacific Northwest is important for stem rust epidemics on wheat, but not for stripe rust. Aeciospores of $P g t$ from barberry are essential inoculum for infecting wheat crops because the uredinial stage is unlikely to survive the winter in the region $[27,28]$. The dormancy of $P g t$ teliospores allows survival during the wet winter with fluctuating temperatures. The wet and fluctuating temperature conditions break the dormancy and allow teliospores to germinate and produce basidiospores at the right time to infect young leaves of barberry in the spring [27]. In contrast, Pst telia are mostly buried into the leaf tissue, and teliospores do not have dormancy. Moreover, Pst teliospores need a much longer (minimum of $32 \mathrm{~h}$ ) continual dew-forming conditions to produce basidiospores and infect barberry than Pgt or Pst urediniospore infection on wheat.

Therefore, a lack of such prolonged period of leaf wetness conditions during the season of telial maturity effectively negates Pst infection in the region. The covered telia, lack of teliospore dominancy, requirement of a long period of dew formation, and sensitivity to degradation make Pst a poor pathogen to coincide with the susceptible stage of alternate hosts [27]. These genetic and physiological characteristics support the poor link between the Pst alternate host and stripe rust epidemics on cereal crops. Based on their results, Wang and Chen [27] pointed out that for being able to infect barberry in a region, Pst requires a relative dry winter to allow teliospores to survive and a wet period in spring when barberry plants produce new leaves. Such climate conditions may occur but likely not every year or in every area. Thus, yearly variations in climatic conditions may affect infection and possibly creates a narrow window for Pst to infect barberry. In contrast, the coincidence of teliospore germination synchronized with new leaf growth of barberry makes Pgt a much better pathogen to infect alternate hosts. Therefore, barberry infection by $P g t$ is more common, and the locations predicted to have high risks can be proven more easily than Pst.

Changing the interval range of MINF for no risk or the low-risk category was observed to be sensitive for substantial changes in proportion of risk locations. The number of locations or frequency under infection suitability scores, particularly for ' 0 ' or 'no risk', varied with the upper limit fixed at 0.01 . Similarly, the number of locations for barberry growth was observed to differ in magnitude particularly for the no suitability ' 0 ' category, when the upper limit was fixed at 0.01 . Estimation of infection suitability can be improved with modification of the interval particularly for the no risk category. More information on barberry infection sites is required. However, changes in the interval upper limit did not affect the comparison of the predicted relative infection risk patterns among the regions. The region-wise risk patterns, instead of individual countries, were more reasonable because the mean values were derived from a large number of sites ( $>30$ sites) and the 
value distributions are closer to normal. The inclusion of Azerbaijan in NWA because of its closeness to Georgia and Turkey would have given a better representation of the regional risk. However, the overall increase in risk gradient from EA to NWA and SEC across the studied regions remained the same.

The role of alternate hosts includes allowing the pathogen to survive seasons without primary hosts under conditions unfavorable to its uredinial stage, providing initial inoculum to start epidemics on cereal crops, and producing new races or genotypes to diversify pathogen populations [26]. However, infection of alternate hosts by a rust fungus may not occur in all areas where the disease occurs on a cereal crop. As mentioned above, barberry does not play a role in stripe rust epidemics in the US Pacific Northwest, while it is essential for stem rust in the region as barberry provides aeciospores as a major initial inoculum for infecting cereal crop [27,28]. Similarly, Pgt is commonly found on barberry in some of the European countries but not Pst [34]. For many regions, urediniopores are major inocula for epidemics of rusts, especially stripe rust, on cereals. Urediniospores can disperse hundreds or thousands of kilometers to spread the disease [1-5,12,58]. For generating races and diversifying the pathogen population, sexual recombination is a quick process as a large number of races or genotypes can be detected in a single field or generated from a single isolate $[24,28,65,68,69]$. However, mutation and somatic recombination have been proven to be major mechanisms for generating variation of both Pst and Pgt [35,70-75]. As the role of alternate hosts on rusts on cereals, especially stripe rust, is less clear in many regions of the world, the present study attempted to estimate the risk of barberry infection by both Pst and Pgt in Asia and the surrounding European countries.

The data of infection risk on barberry obtained in the present study should be useful in global surveillance on barberry infection by Pst and Pgt and in the determination of the epidemiological roles of barberry infection in the development of the rust diseases on cereal crops. Potential risk and spatial patterns are necessary information for developing a prioritized plan for barberry surveillance within a country or geographic region. The assessment framework could be used to assess infection risks for other regions-Africa, the rest of Europe, South America, and North America to identify potential locations for barberry infection and their role in sexual reproduction. Further, the information may serve as guidance for monitoring race changes and deciphering the possible evolutionary mechanisms of pathogen variation. The assessment framework for rust favorable weather conditions and the period of occurrence would help monitor and manage rusts on cereal crops and possible other diseases in the regions. The current study provides only comparative risk assessment among the regions of the studied regions. Nevertheless, the findings may be useful in barberry surveillance programs as well as to test hypotheses in resolving many issues on wheat rust epidemics. The hypothesis put forward particularly for stripe rust infection in barberry is how its infection is constrained by several factors in comparison with stem rust.

Yearly variation in weather, comparatively long hours of leaf wetness, absence of telial dormancy, as well as barberry growth and its susceptibility make a narrow window for infection. Further work is needed to determine the infectivity of rust pathogens on different Berberis and Mahonia species, risk assessment in different locations (grids) within the $1200 \mathrm{~m}$ altitudes using precise weather data, and monitoring barberry infection in nearby wheat fields to resolve the long-standing issue of sexual recombination and the role of alternate hosts.

\section{Materials and Methods}

\subsection{Selection of Locations}

To assess environmental suitability based on meteorological data, a total of 607 locations were selected from 37 countries in East Asia (EA), Central Asia (CA), Northwest Asia (NWA), Southwest Asia (SWA), and adjacent Southeast European countries (SEC). The number of the locations in each country, together with reports of stripe rust and stem rust and the presence of Berberis spp., is summarized in Table 1. The elevation, latitude, and 
longitude of these locations are provided in Table S1. The locations in individual countries for each sub-region were selected using a stratified sampling method. Stratification of categories was based on elevations: negative to 500, 501-1400, 1401-2000, 2001-3000, and above $3001 \mathrm{~m}$ above sea level. To represent a sub-region, at least one location was included based on their relative size and homogeneity.

\subsection{Framework to Assess Potential Infection Risk}

For assessment of rust-favorable weather conditions in each location, a mechanistic infection model, where temperature and leaf wetness or high $\mathrm{RH}(>95 \%) \mathrm{h}$ were used to estimate an index for rust infection, was implemented. As described in more detail below, rust-favorable weather conditions in terms of monthly infection index (MINF) and the number of favorable months (Fav-month) were estimated separately for Pst and Pgt at each location. To determine environmental suitability for barberry infection, a favorable index (MINF $\times$ Fav-month) was calculated, and a risk category of basidiospore infection was assigned. Similarly, to locate possible habitats for barberry growth, a development growth index (NHTT) and the number of favorable months (Fav-month) were estimated; and based on the favorable growth index (NHTT $x$ Fav-month), a suitability score for barberry presence was assigned. For each location, the potential infection risk of barberry was assessed based on the favorable index score for infection and barberry growth. The assessment framework is illustrated in Figure 6.

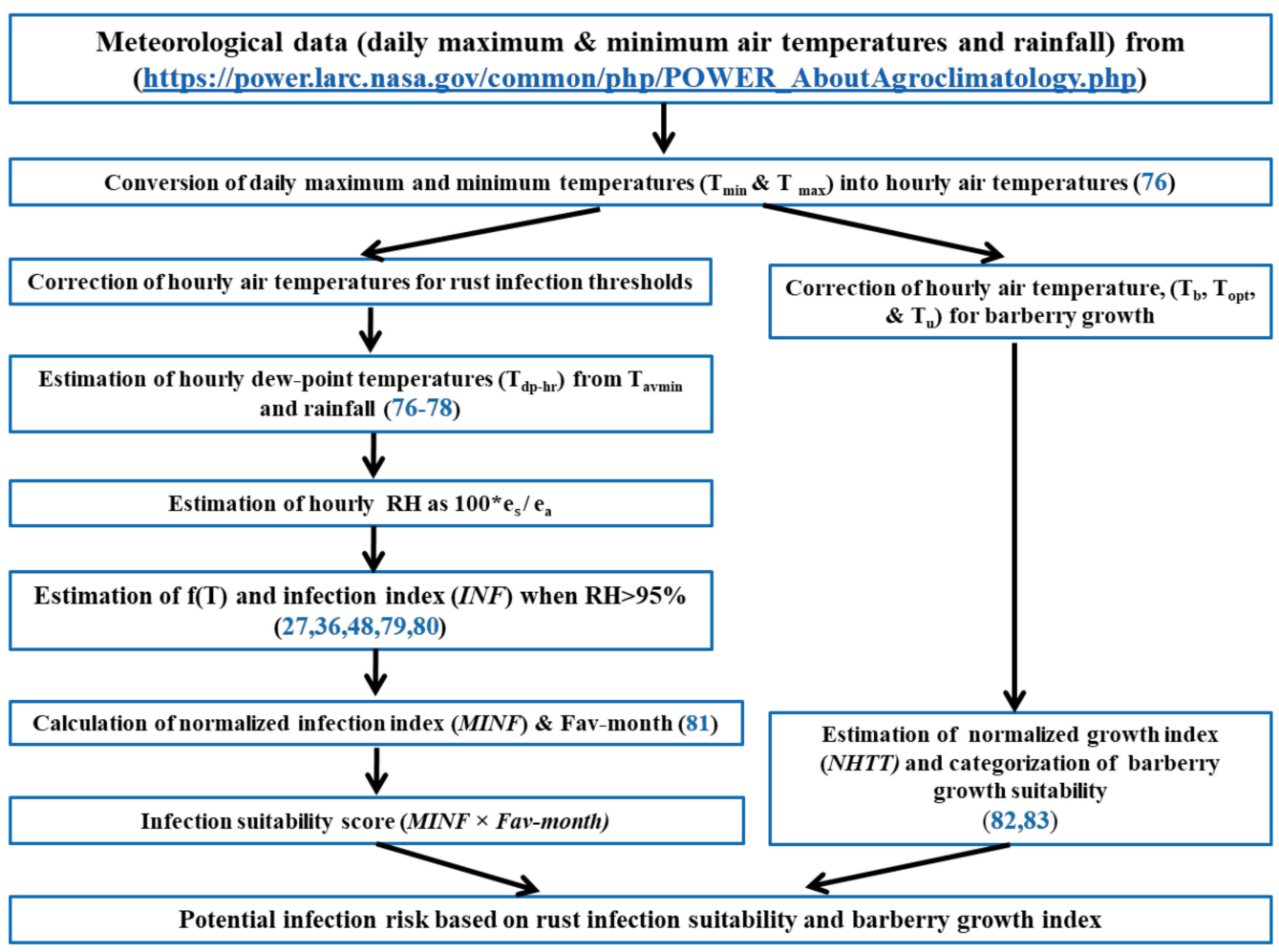

Figure 6. Modeling framework in the assessment of environmental suitability for basidiospore infection in barberry based on meteorological data (https:/ / power.larc.nasa.gov/, accessed on 10 August 2019).

\subsection{Meteorological Data}

Daily maximum $\left(\mathrm{T}_{\max }\right)$, minimum $\left(\mathrm{T}_{\min }\right)$, dew point $\left(\mathrm{T}_{\mathrm{dew}}\right)$ temperatures, and precipitation (mm) from 2010 to 2017 were collected from the National Aeronautics and Space Administration (NASA) website Agroclimatology archive (https:/ / power.larc.nasa.gov, accessed on 10 August 2019). The archive is a repository of weather variables (available 
in $1^{\circ}$ latitude by $1^{\circ}$ longitude grid) derived from satellite observations and formatted for input to crop models.

\subsection{Estimation of Hourly Temperature and High RH (>95\%) for Rust Infection}

Daily minimum $\left(\mathrm{T}_{\min }\right)$ and maximum $\left(\mathrm{T}_{\max }\right)$ temperatures at each location were converted into hourly temperatures $\left(\mathrm{T}_{\text {air-h }}\right)$ using the standard formula [76,77], which provides a smooth transition from minimum to maximum daily air temperatures.

$$
\mathrm{T}_{\text {air }-\mathrm{h}}=\left(\mathrm{T}_{\max }+\mathrm{T}_{\min }\right) / 2+\left(\mathrm{T}_{\max }-\mathrm{T}_{\min }\right) / 2 \times \cos (0.2618 \times(\mathrm{h}-\text { TimeVar })
$$

where TimeVar is the $\mathrm{h}$ of the day corresponding to the time of occurrence of $\mathrm{T}_{\max }$. Hourly $\mathrm{RH}\left(\mathrm{RH}_{\text {air-h }}\right)$ was calculated as:

$$
\mathrm{RH}_{\mathrm{air}-\mathrm{h}}=100 \times \mathrm{e}_{\mathrm{a}} / \mathrm{e}_{\mathrm{s}}
$$

where $e_{a}$ and $e_{s}$ are the hourly actual and saturated vapor pressures, respectively [76]. Actual and saturated vapor pressures were calculated as:

$$
\mathrm{e}_{\mathrm{a}}=0.6108 \exp \left[\left(17.27 \times \mathrm{T}_{\mathrm{dp}-\mathrm{hr}}\right) /\left(\mathrm{T}_{\mathrm{dp}-\mathrm{hr}}+273.3\right)\right]
$$

and

$$
\mathrm{e}_{\mathrm{s}}=0.6108 \exp [(17.27 \times \mathrm{T}) /(\mathrm{T}+273.3)]
$$

where $T_{d p}-h r$ is the hourly dew point temperature. Hourly dew point temperatures $\left(\mathrm{T}_{\mathrm{dp}-\mathrm{hr}}\right)$ and site-specific $\mathrm{T}_{\mathrm{dp}-\mathrm{hrmax}}[78]$ were calculated as:

$$
\mathrm{T}_{\mathrm{dp}-\mathrm{hr}}=\operatorname{Min}\left(\mathrm{T}_{\mathrm{air}-\mathrm{h}}, \mathrm{T}_{\mathrm{dp}-\mathrm{hrmax}}\right)
$$

and

$$
\mathrm{T}_{\mathrm{dp}-\mathrm{hrmax}}=1.510+0.83 \times \mathrm{T}_{\text {avmin }}+0.17 \times \mathrm{R}_{\text {days }}
$$

where $T_{d p}-$ hrmax is the maximum dew point temperature $\left(T_{d p}-h r\right), T_{a v m i n}$, the monthly average minimum temperature, and $R_{\text {days }}$, the monthly days of rainfall (above $3 \mathrm{~mm}$ ).

\subsection{Estimation of Environmental Suitability for Infection}

First, rust infection indices (INF) for Pst and Pgt were calculated separately using the temperatures and high RH hours $(\geq 95 \%)$ at each location. To relate the effect of temperature, a temperature function $f(\mathrm{~T})$ was used [46,79], which utilizes the pathogen's cardinal temperatures to estimate the shape and response:

$f(\mathrm{~T})=\left[\left(\mathrm{T}_{\text {upper }}-\mathrm{T}_{\text {air-h }}\right) /\left(\mathrm{T}_{\text {upper }}-\mathrm{T}_{\text {opt }}\right)\right] \times\left[\left(\mathrm{T}_{\text {air-h }}-\mathrm{T}_{\text {lower }}\right) /\left(\mathrm{T}_{\text {opt }}-\mathrm{T}_{\text {lower }}\right)\right]^{\wedge}\left(\mathrm{T}_{\text {opt }}-\mathrm{T}_{\text {lower }}\right) /\left(\mathrm{T}_{\text {upper }}-\mathrm{T}_{\text {opt }}\right)$

where $f(\mathrm{~T})=$ temperature response to rust infection (scaled between 0 and 1 ); $\mathrm{T}_{\text {lower }}$ and $\mathrm{T}_{\text {upper }}$ are the lower and upper thresholds, respectively for infection beyond which infection is assumed to be zero; and $\mathrm{T}_{\mathrm{opt}}=$ optimum temperature for infection. For the combined effect of temperature $\left(\mathrm{T}_{\text {air-h }}\right.$ ) and high RH hours (h) on infection index (INF), Richards's function that combines $\mathrm{RH}$-hours (h) with temperature-dependent parameters $\mathrm{m}$ and $f(\mathrm{~T})$ was used $[36,48,49,80]$ :

$$
\operatorname{INF}(h)=f(\mathrm{~T}) \times(1-\operatorname{EXP}(-b \times(h-m)))
$$

where $h=\mathrm{RH}$ hours $\geq 95 \% ; m=$ minimum RH-h required for barberry infection; $f(\mathrm{~T})=$ maximum infection index (as asymptote); and $b=$ measure of the rate of change in INF with $h$. A value $b=0.117$ as estimated for the leaf rust pathogen Puccinia triticina [48] was applied for both Pst and Pgt; and m values 32 and $24 \mathrm{~h}$ were used for Pst and Pgt, respectively [27]. 
For each location (with 8-year data), month-wise average INF (AINF) and then monthly AINF (MAINF) were calculated. The MAINF values were then normalized [81] and expressed as $M I N F_{i}$ for comparison among locations.

$$
\begin{aligned}
& A I N F=\sum_{k=1}^{8 \text { year }}(I N F) / 8 \\
& \text { MAINF }=\sum_{k=\text { January }}^{\text {December }}(\text { AINF) } / 12 \\
& \mathrm{MINF}_{\mathrm{i}}=\left(\mathrm{MAINF}_{\mathrm{i}}-\mathrm{MAINF}_{\min }\right) /\left(\mathrm{MAINF}_{\max }-\mathrm{MAINF}_{\min }\right)
\end{aligned}
$$

where $M I N F_{i}$ is the infection index for the $i$-th location and MAINF max and $M A I N F_{\text {min }}$ are the maximum and minimum values for each location, respectively. Location-wise Fav-month was calculated by counting the months having MINF $>0$ and then expressed as a proportion by dividing the value by 12 .

To estimate an infection suitability score for each location, the product of rust infection index (MINF) and Fav-month was categorized into: (1) no (N) risk when the score was 0-0.0090; low (L) risk between 0.0091 and 0.1000; moderate (M) risk for 0.1001-0.3000; high $(\mathrm{H})$ risk 0.3001-0.7000; and very high $(\mathrm{VH})$ risk above 0.7000. Risk scores were assigned based on the presence of barberry infection of Pst and/or Pgt reported particularly for China, India, and Pakistan among the Asian countries [24,26]. Infection suitability scores were plotted on global and regional maps using software ArcGis 10.0 (ESRI, Redlands, CA, USA).

\subsection{Barberry Growth Favorable Index}

Barberry growth at each location was estimated based on hourly thermal times (HTT) using a nonlinear method [82,83]. For estimation of HTT, cardinal temperatures $\left(T_{b}=0{ }^{\circ} \mathrm{C}, T_{u}=30{ }^{\circ} \mathrm{C}\right.$, and $T_{\text {opt }}=22{ }^{\circ} \mathrm{C}$ ) for seed germination with respect to $B$. vulgaris were used $[66,84]$. For each location (with 8-year data), HTT and the monthly average (AHTT) were estimated as:

$$
\begin{gathered}
H T T=\left[\left(T_{h}-T_{b}\right) /\left(T_{o p t}-T_{b}\right)\right] \times\left[\left(T_{u}-T_{h}\right) /\left(T_{u}-T_{o p t}\right)\right]\left(T_{u}-T_{o p t}\right) /\left(T_{o p t}-T_{b}\right) \\
A H T T=\sum_{k=1}^{8}(H T T) / 8
\end{gathered}
$$

where $T_{h}=$ hourly temperature, $T_{b}=$ base temperature, $T_{u}=$ upper threshold temperature, and $T_{\text {opt }}=$ optimum temperature for barberry growth. Monthly AHTT (MHTT) was then calculated as the mean of 12 months for each location as:

$$
\text { MHTT }=\sum_{k=\text { January }}^{\text {December }}(\text { AHTT }) / 12
$$

The MHTT values were normalized [81] and expressed as NHTT for comparison of barberry growth among locations.

$$
\mathrm{NHTT}_{\mathrm{i}}=\left(\mathrm{MHTT}_{\mathrm{i}}-\mathrm{MHTT}_{\min }\right) /\left(\mathrm{MHTT}_{\max }-\mathrm{MHTT}_{\min }\right)
$$

where $\mathrm{NHTT}_{i}$ is the favorable growth index for the $i$-th location and $\mathrm{MHTT}_{\text {max }}$ and $\mathrm{MHTT}_{\min }$ are the maximum and minimum values for the location, respectively. The number of favorable months (Fav-month) for each location was calculated by counting the number of months having $\mathrm{NHTT}_{i}>20$. Barberry suitability index values for individual locations were estimated as a product of $\mathrm{NHTT}_{i}$ and Fav-month and assigned suitability scores based on the global distribution of barberries from the Global Biodiversity Information Facility (https: / / www.gbif.org, accessed on 23 October 2020) and the existence of published reports of Berberis spp. in the region (Table 3). The categories of the barberry growth suitability score are as follows: no or least favorable $(\mathrm{N})$ when the product value was between 0 and 0.1000 , low (L) growth, 0.1001 to 0.3000 , moderate (M) growth, 0.3001 to 0.5000 , high $(\mathrm{H})$ growth, $0.5000-0.7000$, and very high $(\mathrm{VH})$ growth when $\geq 0.7001$. 
Table 3. Number of sites in Asian and adjoining Southeast European countries selected for assessment of favorable conditions for barberry infection by Puccinia striiformis f. sp. tritici and P. graminis f. sp. tritici, references for the occurrence of stripe rust and stem rust, and presence of Berberis spp. and references.

\begin{tabular}{|c|c|c|c|}
\hline Regions & No. of Locations & $\begin{array}{l}\text { References of Stripe and } \\
\text { Stem Rusts on Cereals }\end{array}$ & Berberis spp. (References) \\
\hline \multicolumn{4}{|l|}{ East Asia } \\
\hline Bangladesh & 5 & {$[49,85]$} & Berberis spp. $\left(\mathrm{GBIF}^{\mathrm{a}}\right)$ \\
\hline Bhutan & 9 & {$[86,87]$} & Berberis spp. [64]; (GBIF) \\
\hline China & 142 & {$[22,88]$} & $\begin{array}{c}\text { B. aggregata, B. aggregata var. } \\
\text { integrifolia, B. atrocarpa, } B . \\
\text { brachypoda, B. chinensis, } B . \\
\text { circumserrata, B. dasystachya, } B \text {. } \\
\text { davidii, B. ferdinandi-coburgii, B. } \\
\text { guizhouensis, B. holstii, B. } \\
\text { jamesiana, B. koreana, B. phanera, } \\
\text { B. platyphylla, B. poiretii, B. } \\
\text { potaninii, B. shensiana, B. } \\
\text { soulieana, B. stenostachya, B. } \\
\text { vulgaris, B. wangii, etc. } \\
\text { [32,33,89]; (GBIF) }\end{array}$ \\
\hline India & 45 & {$[87,90]$} & B. aristata [91]; (GBIF) \\
\hline Mongolia & 10 & {$[12,58]$} & Data not found \\
\hline Myanmar & 8 & [55] & Berberis spp. [64]; (GBIF) \\
\hline Nepal & 15 & {$[12,87,92]$} & B. aristata [91]; (GBIF) \\
\hline Pakistan & 16 & {$[12,93,94]$} & $\begin{array}{l}\text { B. aitchinsoni, B. baluchistanica, } \\
\text { B. brandisiana, B. brevissima, } B . \\
\text { calliobotrys, B. chitria, } B . \\
\text { glaucocarpa, B. huegeliana, } B . \\
\text { jaeschkeana, B. kashmirana, } B . \\
\text { kunawurensis, B. lyceum, } B . \\
\text { orthobotrys, B. pachyacantha, B. } \\
\text { parkeriana, B. pseudumbellata, B. } \\
\text { royleana, B. stewartiana, B. } \\
\text { ulicina, B. vulgaris [95]; (GBIF) }\end{array}$ \\
\hline \multicolumn{4}{|l|}{ Central Asia } \\
\hline Afghanistan & 20 & [12] & B. vulgaris [96]; (GBIF) \\
\hline Azerbaijan & 16 & {$[13,29]$} & B. vulgaris $[24,66]$; (GBIF) \\
\hline Iran & 58 & {$[16,54]$} & B. vulgaris $[34,64,66] ;(\mathrm{GBIF})$ \\
\hline Kazakhstan & 18 & [63] & B. vulgaris $[24,66] ;(\mathrm{GBIF})$ \\
\hline Kyrgyzstan & 14 & {$[12,58]$} & B. vulgaris $[24,66] ;(\mathrm{GBIF})$ \\
\hline Russia & 23 & {$[16,92]$} & Berberis spp. (GBIF) \\
\hline Tajikistan & 13 & [97] & B. vulgaris $[24,66] ;(\mathrm{GBIF})$ \\
\hline Turkmenistan & 20 & [11] & B. vulgaris $[24,66] ;(\mathrm{GBIF})$ \\
\hline Uzbekistan & 13 & {$[16,97]$} & B. vulgaris $[24,66] ;(\mathrm{GBIF})$ \\
\hline \multicolumn{4}{|l|}{ Northwest Asia } \\
\hline Armenia & 10 & {$[11,29]$} & Berberis spp. (GBIF) \\
\hline Georgia & 9 & [29] & B. vulgaris [96]; (GBIF) \\
\hline Turkey & 40 & {$[13,16]$} & B. vulgaris [96]; (GBIF) \\
\hline \multicolumn{4}{|l|}{ Southwest Asia } \\
\hline Egypt & 20 & {$[13,93,98,99]$} & Berberis spp. (GBIF) \\
\hline Iraq & 5 & {$[13,16,93]$} & Berberis spp. (GBIF) \\
\hline Israel & 2 & {$[13,93]$} & Berberis spp. (GBIF) \\
\hline Lebanon & 1 & {$[13,93]$} & Berberis spp. (GBIF) \\
\hline Oman & 4 & {$[13,93]$} & Berberis spp. (GBIF) \\
\hline Saudi Arabia & 11 & {$[13,93]$} & Berberis spp. (GBIF) \\
\hline Syria & 3 & {$[13,93]$} & Berberis spp. (GBIF) \\
\hline Yemen & 4 & {$[13,93]$} & Berberis spp. (GBIF) \\
\hline
\end{tabular}


Table 3. Cont.

\begin{tabular}{cccc}
\hline Regions & No. of Locations & $\begin{array}{c}\text { References of Stripe and } \\
\text { Stem Rusts on Cereals }\end{array}$ & Berberis spp. (References) \\
\hline $\begin{array}{c}\text { Southeast Europe } \\
\text { Albania }\end{array}$ & 1 & Data not found & Berberis spp. (GBIF) \\
Bulgaria & 10 & {$[93]$} & Berberis spp. (GBIF) \\
Croatia & 2 & {$[16]$} & Berberis spp. (GBIF) \\
Greece & 6 & {$[13]$} & Berberis spp. (GBIF) \\
Italy & 5 & {$[13,16]$} & Berberis spp. (GBIF) \\
Montenegro & 1 & Data not found & Berberis spp. (GBIF) \\
Romania & 12 & Data not found & Berberis spp. [100]; (GBIF) \\
Slovenia & 1 & {$[16]$} & Berberis spp. (GBIF) \\
Ukraine & 15 & & \\
\hline Total & 607 & spiF)
\end{tabular}

\subsection{Analysis for Association of Infection Suitability with Geographic Feature}

Pearson's chi-squared tests were conducted to determine associations of rust infection suitability with location elevation, latitude, and longitude.

\subsection{Comparison of Rust Infection Suitability with Rust Growth Index (GI)}

To validate the rust infection suitability indices obtained from the mechanistic modeling framework (Figure 1), GI, as a measure of environmental suitability for Pst or Pgt infection or barberry growth, was predicted using the Dymex model (Hearne Software, Melbourne, Australia). Their growth indices were estimated using fixed moisture parameters $(\mathrm{M} 0=0.2, \mathrm{M} 1=0.8, \mathrm{M} 2=1.2$, and $\mathrm{M} 3=1.8)$ and temperature thresholds specific to Pst $(\mathrm{DV} 0=0, \mathrm{DV} 1=9, \mathrm{DV} 2=11$, and DV3 = 25), Pgt $(\mathrm{DV} 0=3, \mathrm{DV} 1=20, \mathrm{DV} 2=22$, and DV3 = 30), and barberry (DV0 $=3, \mathrm{DV} 1=20, \mathrm{DV} 2=22$, and DV3 $=30$ ). Stress was not considered in the model. The normalized growth index values for Pst, Pgt, and barberry growth for the regions of interest were then scaled using the same range as used for the assessment of rust infection suitability and barberry favorable growth indices as presented above.

For testing the reliability of infection suitability scores with growth index predicted by the Dymex model, several known locations of barberry infection by Pst and/or Pgt were chosen (particularly in the U.S. Pacific Northwest and western China). Location-wise rust infection suitability scores and barberry growth index (barberry favorable) values were compared with the predicted growth index (GI) categories of rusts and barberry using Cohen's Kappa [101]. The agreement between the suitability scores was interpreted following the standard guidelines [102].

For each location, potential infection risks for Pst and Pgt were assessed separately based on the rust infection suitability and barberry growth index or their suitability scores. Individual locations were categorized into no $(\mathrm{N})$, low $(\mathrm{L})$, moderate $(\mathrm{M})$, high risk $(\mathrm{H})$, or very high $(\mathrm{VH})$ risk based on the concurrence of infection suitability and barberry suitability categories. Locations having either only barberry suitability score or rust infection suitability score, but not both, were categorized to be of no $(\mathrm{N})$ risk. A location having the same category $(\mathrm{L}, \mathrm{M}, \mathrm{H}$, or $\mathrm{VH})$ for both rust infection and barberry growth, potential risk of the same category was assigned for the location. For a location with a higher infection score category but a lower category for barberry growth, or vice versa, the potential risk was assigned to the lower category for the location.

\section{Conclusions}

In the present study, we used mechanistic models to calculate infection indices for both the wheat stripe rust and stem rust pathogens, following similar modeling frameworks for assessing infection risks on barberry. In East Asia, Bhutan, China, and Nepal were found to have low risks of barberry infection by the stripe rust pathogen but high risks by the stem rust pathogen. In Central Asia, Azerbaijan, Iran, Kazakhstan, southern Russia, 
and Uzbekistan were identified to have low to high risks of barberry infection for both pathogens. In Northwest Asia, risk levels of both pathogens in Turkey and the Republic of Georgia were determined to be high to very high. In Southwest Asia, no or low risk was found. In Southeastern Europe, similar high or very high risks for both pathogens were noted for all countries. Although the potential risks of barberry infection by the rust fungi were estimated based on chronological weather s, the results should be useful to guide monitoring barberry infections in the risky regions and could be valuable for developing rust management strategies in these regions. The modeling framework used in this study may be useful to predict rust infection risk on cereal crops and alternate hosts in other regions.

Supplementary Materials: The following are available online at https:/ / www.mdpi.com/article / 10.3390/plants10050957/s1: Table S1: Elevations: latitudes, longitudes, monthly infection index (MINF), Fav-month (F), and infection risk (MINF x F) values of 607 locations for the stripe rust pathogen, Puccinia striiformis $\mathrm{f}$. sp. tritici (Pst) and the stem rust pathogen, P. graminis $\mathrm{f}$. sp. tritici $(P g t)$ in relation to barberry growth in Asia and adjoining European region. Table S2: Numbers and percentages of locations in Asian and Southwest European regions with different stripe rust infection suitability scores. Table S3: Numbers and percentages of locations in Asian and Southwest European regions with different stem rust infection suitability scores. Table S4: Numbers and percentages of locations in Asian and Southwest European regions with different barberry growth suitability scores. Table S5: Scores of infections of Puccinia striiformis $\mathrm{f}$. sp. tritici (Pst) and P. graminis f. sp. tritici $(P g t)$ and barberry growth predicted using the framework of this study and the Dymex model for selected locations in the U.S. Pacific and western China with reported barberry growth and the correlation of the two model results determined using Cohen's Kappa coefficient $(k)$. Figure S1: Sensitivity analysis for parameter $b$ in the mechanistic model used for estimation of infection index $[\operatorname{INF}(h)=\mathrm{f}(\mathrm{T}) \times(1-\operatorname{EXP}(-\mathrm{b} \times(\mathrm{h}-\mathrm{m})))]$ on barberry; $\mathrm{f}(\mathrm{T})=0.9 ; \mathrm{m}=$ leaf wetness hours ( $32 \mathrm{~h}$ for stripe rust and $24 \mathrm{~h}$ for stem rust); and $\mathrm{h}=$ hours of leaf wetness. Figure S2: Infection suitability $(M I N F \times$ Fav-month) for stripe rust (a) and stem rust (b), and barberry growth suitability (c) in Asian and bordering Southeast European regions predicted using the mechanistic model in the framework. Infection suitability: $\mathrm{N}=$ no or very low $(0-0.0090) ; \mathrm{L}=$ low $(0.0091-0.1000)$; $\mathrm{M}=$ moderate (0.1001-0.3000); $\mathrm{H}=$ high (0.3001-0.7000); and $\mathrm{VH}=$ very high $(>0.7000)$. Barberry growth suitability: $\mathrm{N}=$ no or very low (0-0.1000); $\mathrm{L}=$ low $(0.1001-0.3000) ; \mathrm{M}=$ moderate (0.3001$0.5000) ; \mathrm{H}=$ high (0.5001-0.7000); and $\mathrm{VH}=$ very high (>0.7000). Figure S3: Infection suitability $(\mathrm{MINF} \times$ Fav-month) for stripe rust $(\mathbf{A})$ and stem rust $(\mathbf{B})$, and barberry growth suitability $(\mathbf{C})$ in Asian and bordering Southeast European regions predicted using the Dymex model. Infection suitability: $\mathrm{N}=$ no or very low (0-0.0090); $\mathrm{L}=$ low (0.0091-0.1000); $\mathrm{M}=$ moderate $(0.1001-0.3000)$; $\mathrm{H}=$ high (0.3001-0.7000); and $\mathrm{VH}=$ very high ( $>0.7000)$. Barberry growth suitability: $\mathrm{N}=$ no or very low (0-0.1000); $\mathrm{L}=$ low (0.1001-0.3000); $\mathrm{M}=$ moderate (0.3001-0.5000); $\mathrm{H}=$ high (0.5001-0.7000); and $\mathrm{VH}=$ very high $(>0.7000)$.

Author Contributions: Conceptualization, X.C.; methodology, P.S.; software, P.S.; validation, P.S. and X.C.; formal analysis, P.S.; investigation, P.S.; resources, X.C. and P.S.; data curation, P.S.; writing-original draft preparation, P.S.; writing—review and editing, X.C. and P.S.; visualization, P.S.; supervision, X.C.; project administration, X.C and P.S.; funding acquisition, P.S. and X.C. All authors have read and agreed to the published version of the manuscript.

Funding: This research was supported by the US Department of Agriculture, Agricultural Research Service (Project No. 2090-22000-018-00D); Department of Plant Pathology, College of Agricultural, Human, and Natural Resource Sciences, Agricultural Research Center, HATCH Project Number WNP00461, Washington State University, Pullman, WA 99164-6430, USA; and the Fulbright fellowship provided by the Institute of International Education, New York, NY, USA and support by ICAR-IARI New Delhi, India to P. Sinha. Mention of trade names or commercial products in this publication is solely for the purpose of providing specific information and does not imply recommendation or endorsement by the U. S. Department of Agriculture. USDA is an equal opportunity provider and employer.

Institutional Review Board Statement: Not applicable.

Informed Consent Statement: Not applicable. 
Data Availability Statement: All data used in and created by this study are included in this publication as tables, figures, and supplementary files.

Acknowledgments: We thank the editor and reviewers for their valuable comments to improve the manuscript.

Conflicts of Interest: The authors declare no conflict of interest. The funders had no role in the design of the study; in the collection, analyses, or interpretation of data; in the writing of the manuscript, or in the decision to publish the results.

\section{References}

1. Kolmer, J.; Chen, X.M.; Jin, Y. Diseases which challenge global wheat production-The wheat rusts. In Wheat: Science and Trade; Carver, B.F., Ed.; Wiley-Blackwell: Ames, IA, USA, 2009; pp. 89-124.

2. Wellings, C.R. Global status of stripe rust: A review of historical and current threats. Euphytica 2011, 179, 129-141. [CrossRef]

3. Chen, X.M.; Kang, Z.S. History of research, symptoms, taxonomy of the pathogen, host range, distribution, and impact of stripe rust. In Stripe Rust; Chen, X.M., Kang, Z.S., Eds.; Springer: Dordrecht, The Netherlands, 2017; pp. 1-33.

4. Meyer, M.; Burgin, L.; Hort, M.C.; Hodson, D.P.; Gilligan, C.A. Large scale atmospheric dispersal simulations identify likely airborne incursion routes of wheat stem rust into Ethiopia. Phytopathology 2017, 107, 1175-1186. [CrossRef] [PubMed]

5. Meyer, M.; Cox, J.A.; Hitchings, M.D.T.; Burgin, L.; Hort, M.C.; Hodson, D.P.; Gilligan, C.A. Quantifying airborne dispersal routes of pathogens over continents to safeguard global wheat supply. Nat. Plants 2017, 3, 780-786. [CrossRef]

6. Allen-Sader, C.; Thurston, W.; Meyer, M.; Nure, E.; Bacha, N.; Alemayehu, Y.; Stutt, R.O.; Safka, D.; Craig, A.P.; Derso, E.; et al. An early warning system to predict and mitigate wheat rust diseases in Ethiopia. Environ. Res. Lett. 2019, 14, 115004. [CrossRef] [PubMed]

7. Chen, X.M. Epidemiology and control of stripe rust Puccinia striiformis f. sp. tritici on wheat. Can. J. Plant Pathol. 2005, 27, 314-337. [CrossRef]

8. Chen, X.M.; Penman, L.; Wan, A.M.; Cheng, P. Virulence races of Puccinia striiformis f. sp. tritici in 2006 and 2007 and development of wheat stripe rust and distributions, dynamics, and evolutionary relationships of races from 2000 to 2007 in the United States. Can. J. Plant Pathol. 2010, 32, 315-333. [CrossRef]

9. Chen, X.M. Pathogens which threaten food security: Puccinia striiformis, the wheat stripe rust pathogen. Food Secur. 2020, 12, 239-251. [CrossRef]

10. Morgounov, A.; Tufan, H.A.; Sharma, R.; Akin, B.; Bagci, A.; Braun, H.-J.; Kaya, Y.; Keser, M.; Payne, T.S.; Sonder, K.; et al. Global incidence of wheat rusts and powdery mildew during 1969-2010 and durability of resistance of winter wheat variety Bezostaya 1. Eur. J. Plant Pathol. 2012, 132, 323-340. [CrossRef]

11. Ziyaev, Z.M.; Sharma, R.C.; Nazari, K.; Morgounov, A.I.; Amanov, A.A.; Ziyadullaev, Z.F.; Khalikulov, Z.I.; Alikulov, S.M. Improving wheat stripe rust resistance in Central Asia and the Caucasus. Euphytica 2011, 179, 197-207. [CrossRef]

12. Ali, S.; Gladieux, P.; Leconte, M.; Gautier, A.; Justesen, A.F.; Hovmøller, M.S.; Enjalbert, J.; de Vallavieille-Pope, C. Origin, migration routes and worldwide population genetic structure of the wheat yellow rust pathogen Puccinia striiformis f.sp. tritici. PLoS Pathog. 2014, 10, e1003903. [CrossRef]

13. GRRC. New Races Caused Epidemics of Yellow Rust in Europe, East Africa and Central Asia in 2016. Global Rust Reference Center, Aarhus University, Denmark. 2017. Available online: https://agro.au.dk/forskning/internationale-platforme/wheatrust/newsand-events / news-item/artikel/new-races-caused-epidemics-of-yellow-rust-in-europe-east-africa-and-central-asia-in-2016/ (accessed on 30 March 2021).

14. Hodson, D.; Nazari, K. Serious Outbreaks of Wheat Stripe Rust or Yellow Rust in Central and West Asia and North Africa, March/April 2010. 2010. Available online: https://globalrust.org/traction/permalink/Pathogen206 (accessed on 30 March 2021).

15. Chen, X.M. Challenges and solutions for stripe rust control in the United States. Aust. J. Agric. Res. 2007, 58, 648-655. [CrossRef]

16. Hovmøller, M.S.; Rodriguez-Algaba, J.; Thach, T.; Justesen, A.F.; Hansen, J.G. Report for Puccinia striiformis Race Analyses and Molecular Genotyping 2017, Global Rust Reference Center (GRRC), Aarhus University, Denmark. 2018. Available online: https://wheatrust.org/fileadmin/www.grcc.au.dk/International_Services/Pathotype_YR_results/Summary_of_Puccinia_ striiformis_race_analysis_2017.pdf (accessed on 30 March 2021).

17. Beddow, J.M.; Pardey, P.G.; Chai, Y.; Hurley, T.M.; Kriticos, D.J.; Braun, J.; Park, R.F.; Cuddy, W.S.; Yonow, T. Research investment implications of shifts in the global geography of wheat stripe rust. Nat. Plants 2015, 1, 15132. [CrossRef] [PubMed]

18. Milus, E.A.; Kristensen, K.; Hovmoller, M.S. Evidence for increased aggressiveness in a recent widespread strain of Puccinia striiformis f. sp. tritici causing stripe rust of wheat. Phytopathology 2009, 99, 89-94. [CrossRef] [PubMed]

19. Garrett, K.A.; Dendy, S.P.; Frank, E.E.; Rouse, M.N.; Travers, S.E. Climate change effects on plant disease: Genomes to ecosystems. Annu. Rev. Phytopathol. 2006, 44, 489-509. [CrossRef]

20. Park, R.; Fetch, T.; Hodson, D.; Jin, Y.; Nazari, K. International surveillance of wheat rust pathogens, progress and challenges. Euphytica 2011, 179, 109-117. [CrossRef]

21. Pardey, P.G.; Beddow, J.M.; Kriticos, D.J.; Hurley, T.M.; Park, R.E.; Duveiller, E.; Sutherst, R.W.; Burdon, J.J.; Hodson, D. Right-sizing stem rust research. Science 2013, 340, 147-148. [CrossRef]

22. Li, Z.Q.; Zeng, S.M. Wheat Rusts in China; China Agricultural Press: Beijing, China, 2002; p. 479. 
23. Lewis, C.M.; Persoons, A.; Bebber, D.P.; Kigathi, R.N.; Maintz, J.; Findlay, K.; Bueno-Sancho, V.; Corredor-Moreno, P.; Harrington, S.A.; Kangara, N.; et al. Potential for re-emergence of wheat stem rust in the United Kingdom. Commun. Biol. $2018,1,13$. [CrossRef]

24. Jin, Y.; Szabo, L.J.; Carson, M. Century-old mystery of Puccinia striiformis life history solved with the identification of Berberis as an alternate host. Phytopathology 2010, 100, 432-435. [CrossRef]

25. Wang, M.N.; Chen, X.M. First report of Oregon grape (Mahonia aquifolium) as an alternate host for the wheat stripe rust pathogen (Puccinia striiformis f. sp. tritici) under artificial inoculation. Plant Dis. 2013, 97, 839. [CrossRef]

26. Zhao, J.; Wang, M.N.; Chen, X.M.; Kang, Z.S. Role of alternate hosts in epidemiology and pathogen variation of cereal rusts. Annu. Rev. Phytopathol. 2016, 54, 207-228. [CrossRef]

27. Wang, M.N.; Chen, X.M. Barberry does not function as an alternate host for Puccinia striiformis f. sp. tritici in the US Pacific Northwest due to teliospore degradation and barberry phenology. Plant Dis. 2015, 99, 1500-1506. [CrossRef]

28. Wang, M.N.; Wan, A.M.; Chen, X.M. Barberry as alternate host is important for Puccinia graminis f. sp. tritici but not for Puccinia striiformis f. sp. tritici in the U. S. Pacific Northwest. Plant Dis. 2015, 99, 1507-1516. [CrossRef]

29. Ali, S.; Leconte, M.; Walker, A.-S.; Enjalbert, J.; de Vallavieille-Pope, C. Reduction in the sex ability of worldwide clonal populations of Puccinia striiformis f. sp. tritici. Fungal Genet. Biol. 2010, 47, 828-838. [CrossRef]

30. Ali, S.; Gladieux, P.; Rahman, H.; Saqib, M.S.; Fiaz, M.; Ahmad, H.; Leconte, M.; Gautier, A.; Justesen, A.F.; Hovmøller, M.S.; et al. Inferring the contribution of sexual reproduction, migration and off-season survival to the temporal maintenance of microbial populations: A case study on the wheat fungal pathogen Puccinia striiformis f.sp. tritici. Mol. Ecol. 2014, 23, 603-617. [CrossRef]

31. Bahri, B.; Shah, S.J.A.; Hussain, S.; Leconte, M.; Enjalbert, J.; de Vallavieille-Pope, C. Genetic diversity of the wheat yellow rust population in Pakistan and its relationship with host resistance. Plant Pathol. 2011, 60, 649-660. [CrossRef]

32. Zhao, J.; Wang, L.; Wang, Z.Y.; Chen, X.M.; Zhang, H.C.; Yao, J.N.; Zhan, G.M.; Chen, W.; Huang, L.L.; Kang, Z.S. Identification of eighteen Berberis species as alternate hosts of Puccinia striiformis f. sp. tritici and virulence variation in the pathogen isolates from natural infection of barberry plants in China. Phytopathology 2013, 103, 927-934. [CrossRef]

33. Wang, Z.Y.; Zhao, J.; Chen, X.M.; Peng, Y.L.; Ji, J.J.; Zhao, S.L.; Lu, Y.J.; Huang, L.L.; Kang, Z.S. Virulence variations of Puccinia striiformis f. sp. tritici isolates collected from Berberis spp. in China. Plant Dis. 2016, 100, 131-138. [CrossRef]

34. Berlin, A.; Djurle, A.; Samils, B.; Yuen, J. Genetic variation in Puccinia graminis collected from oats, rye, and barberry. Phytopathology 2012, 102, 1006-1012. [CrossRef]

35. Hovmøller, M.S.; Sørensen, C.K.; Walter, S.; Justesen, A.F. Diversity of Puccinia striiformis on cereals and grasses. Annu. Rev. Phytopathol. 2011, 49, 197-217. [CrossRef]

36. De Vallavieille-Pope, C.; Huber, L.; Leconte, M.; Goyeau, H. Comparative effects of temperature and interrupted wet periods on germination, penetration, and infection of Puccinia recondita f. sp. tritici and P. striiformis on wheat seedlings. Phytopathology 1995, 85, 409-415. [CrossRef]

37. Chen, X.M. Stripe rust epidemiology. In Stripe Rust; Chen, X.M., Kang, Z.S., Eds.; Springer: Dordrecht, The Netherlands, 2017; pp. 283-352.

38. Burrage, S.W. Environmental factors influencing the infection of wheat by Puccinia graminis. Ann. Appl. Biol. 1970, 66, 429-440. [CrossRef]

39. Coakley, S.M.; Boyd, W.S.; Line, R.F. Statistical models for predicting stripe rust on winter wheat in the Pacific Northwest. Phytopathology 1982, 72, 1539-1542. [CrossRef]

40. Roelfs, A.P. Wheat and rye stem rust. In The Cereal Rusts; Roelfs, A.P., Bushnell, W.R., Eds.; Academic Press: Orlando, FL, USA, 1985; pp. 3-37.

41. Dennis, J.I. Temperature and wet-period conditions for infection by Puccinia striiformis f. sp. tritici race 104E137Af. Trans. Br. Mycol. Soc. 1987, 88, 119-121. [CrossRef]

42. Ellison, P.J.; Murray, G.M. Epidemiology of Puccinia striiformis f. sp. tritici on wheat in southern New South Wales. Aust. J. Agric. Res. 1992, 43, 29-41. [CrossRef]

43. Line, R.F. Stripe rust of wheat and barley in North America: A retrospective historical review. Annu. Rev. Phytopathol. 2002, 40, 75-118. [CrossRef]

44. Sharma-Poudyal, D.; Chen, X.M.; Rupp, R. Potential oversummering and overwintering regions for the wheat stripe rust pathogens in the contiguous United States. Int. J. Biometeorol. 2014, 58, 987-997. [CrossRef]

45. Merow, C.; LaFleur, N.; Silander, J.A., Jr.; Wilson, A.M.; Rubega, M. Developing dynamic mechanistic species distribution models: Predicting bird-mediated spread of invasive plants acrosss Northeastern North America. Am. Nat. 2011, 178, 30-43. [CrossRef]

46. Magarey, R.D.; Sutton, T.B.; Thayer, C.L. A simple generic infection model for foliar fungal pathogens. Phytopathology 2005, 95, 92-100. [CrossRef]

47. Bregaglio, S.; Cappelli, G.; Donatelli, M. Evaluating the suitability of a generic fungal infection model for pest risk assessment studies. Ecol. Model. 2012, 247, 58-63. [CrossRef]

48. Launay, M.; Caubel, J.; Bourgeois, G.; Huard, F.; de Cortazar-Atauri, I.G.; Bancal, M.; Brisson, N. Climatic indicators for crop infection risk: Application to climate change impacts on five major foliar fungal diseases in Northern France. Agric. Ecosyst. Environ. 2014, 197, 147-158. [CrossRef]

49. Viswanath, K.; Sinha, P.; Kumar, S.N.; Sharma, T.; Saxena, S.; Panjwani, S.; Pathak, H.; Shukla, S.M. Simulation of leaf blast infection in tropical rice agro-ecology under climate change scenario. Clim. Chang. 2017, 142, 155-167. [CrossRef] 
50. Sutherst, R.W.; Maywald, G.F. A computerised system for matching climates in ecology. Agric. Ecosys. Environ. 1985, 13, 281-299. [CrossRef]

51. Hodson, D.; DePauw, E. Use of GIS Applications to combat the threat of emerging virulent wheat stem rust races. In Applications in Agriculture: Invasive Species; Clay, S., Ed.; Taylor \& Francis Press: Abingdon, UK, 2010; pp. 129-157.

52. Venette, R.C.; Kriticos, D.J.; Magarey, R.D.; Koch, F.H.; Baker, R.H.A.; Worner, S.P.; Raboteaux, N.N.G.; Mckenney, D.W.; Dobesberger, E.J.; Yem Shanov, D.; et al. Pest risk maps for invasive alien species: A roadmap for improvement. Bioscience 2010, 60, 349-362. [CrossRef]

53. Rapilly, F. Yellow rust epidemiology. Annu. Rev. Phytopathol. 1979, 17, 59-73. [CrossRef]

54. Roelfs, A.P.; Singh, R.P.; Saari, E.E. Rust Diseases of Wheat: Concepts and Methods of Diseases Management; CIMMYT: Mexico City, Mexico, 1992; pp. 1-89.

55. Stubbs, R.W. Stripe rust. In The Cereal Rusts, Vol. 2, Diseases, Distribution, Epidemiology, and Control; Roelfs, A.P., Bushnell, W.R., Eds.; Academic Press: Orlando, FL, USA, 1985; pp. 61-101.

56. Zhao, J.; Zhao, S.L.; Chen, X.M.; Wang, Z.Y.; Wang, L.; Yao, J.N.; Chen, W.; Huang, L.L.; Kang, Z.S. Determination of the role of Berberis spp. in wheat stem rust in China. Plant Dis. 2015, 99, 1113-1117. [CrossRef]

57. Mehmood, S.; Sajid, M.; Zhao, J.; Khan, T.; Zhan, G.; Huang, L.; Kang, Z. Identification of Berberis species collected from the Himalayan region of Pakistan susceptible to Puccinia striiformis f. sp. tritici. Plant Dis. 2019, 103, 461-467. [CrossRef]

58. Hovmøller, M.S.; Yahyaoui, A.H.; Milus, E.A.; Justesen, A.F. Rapid global spread of two aggressive strains of a wheat rust fungus Mol. Ecol. 2008, 17, 3818-3826. [CrossRef]

59. Mboup, M.; Leconte, M.; Gautier, A.; Wan, A.M.; Chen, W.Q.; de Vallavieille-Pope, C.; Enjalbert, J. Evidence of genetic recombination in wheat yellow rust populations of a Chinese oversummering area. Fungal Genet. Biol. 2009, 46, $299-307$. [CrossRef]

60. Thach, T.; Ali, S.; de Vallavieille-Pope, C.; Justesen, A.F.; Hovmøller, M.S. Worldwide population structure of the wheat rust fungus Puccinia striiformis in the past. Fungal Genet. Biol. 2016, 87, 1-8. [CrossRef]

61. Walter, S.; Ali, S.; Kemen, E.; Nazari, K.; Bahri, B.; Enjalbert, J. Molecular markers for tracking the origin and worldwide distribution of invasive strains of Puccinia striiformis. Ecol. Evol. 2016, 6, 2790-2804. [CrossRef]

62. Ciuca, M.; Cristina, D.; Turcu, A.G.; Contescu, E.L.; Ionescu, V.; Saulescu, N.N. Molecular detection of the adult plant leaf rust resistance gene Lr34 in Romanian winter wheat germplasm. Cereal Res. Commun. 2015, 43, 249-259. [CrossRef]

63. Morgounov, A.; Roseeva, L.; Koishibayev, M. Leaf rust of spring wheat in northern Kazakhstan and Siberia: Incidence, virulence and breeding for resistance. Aust. J. Agric. Res. 2007, 58, 847-853. [CrossRef]

64. Hansen, J.G.; Lassen, P.; Justesen, A.F.; Nazari, K.; Hodson, D.; Hovmøller, M. Barberry rust survey developing tools for data management and dissemination. In Global Rust Reference Center Report, 2013; Aarhus University: Flakkebjerg, Denmark, 2013; p. 15. Available online: https://agro.au.dk/fileadmin/BarberryReport_V4.pdf (accessed on 23 October 2020).

65. Jin, Y. Role of Berberis spp. as alternate hosts in generating new races of Puccinia graminis and P. striiformis. Euphytica 2011, 179, 105-108. [CrossRef]

66. Gucker, C.L. Berberis Vulgaris. In Fire Effects Information System; U.S. Department of Agriculture, Forest Service, Rocky Mountain Research Station, Fire Sciences Laboratory: Washington, DC, USA, 2009. Available online: https://www.fs.fed.us/database/feis/ plants/shrub/bervul/all.html (accessed on 30 March 2021).

67. Li, S.; Chen, W.; Ma, X.; Tian, X.; Liu, Y.; Huang, L.; Kang, Z.; Zhao, J. Identification of eight Berberis species from the YunnanGuizhou plateau as aecial hosts for Puccinia striiformis f. sp. tritici, the wheat stripe rust pathogen. J. Integr. Agric. 2020, $19,2-8$.

68. Yuan, C.Y.; Wang, M.N.; Skinner, D.Z.; See, D.R.; Xia, C.J.; Guo, X.H.; Chen, X.M. Inheritance of virulence, construction of a linkage map, and mapping of virulence genes in Puccinia striiformis $\mathrm{f}$. sp. tritici by virulence and molecular characterization of a sexual population through genotyping-by-sequencing. Phytopathology 2018, 108, 133-141. [CrossRef]

69. Xia, C.J.; Lei, Y.; Wang, M.N.; Chen, W.Q.; Chen, X.M. An avirulence gene cluster in the wheat stripe rust pathogen (Puccinia striiformis $\mathrm{f}$. sp. tritici) identified through genetic mapping and whole-genome sequencing of a sexual population. $m S p h e r e \mathbf{2 0 2 0}$ 5, e00128-20. [CrossRef]

70. Wellings, C.R.; McIntosh, R.A. Puccinia striiformis f.sp. tritici in Australasia: Pathogenic changes during the first 10 years. Plant Pathol. 1990, 39, 316-325. [CrossRef]

71. Chen, J.; Upadhyaya, N.M.; Ortiz, D.; Sperschneider, J.; Li, F.; Bouton, C.; Breen, S.; Dong, C.; Xu, B.; Zhang, X.; et al. Loss of AvrSr50 by somatic exchange in stem rust leads to virulence for Sr50 resistance in wheat. Science 2017, 358, 1607-1610. [CrossRef] [PubMed]

72. Lei, Y.; Wang, M.N.; Wan, A.M.; Xia, C.J.; See, D.R.; Zhang, M.; Chen, X.M. Virulence and molecular characterization of experimental isolates of the stripe rust pathogen (Puccinia striiformis) indicate somatic recombination. Phytopathology 2017, 107, 329-344. [CrossRef] [PubMed]

73. Li, F.; Upadhyaya, N.M.; Sperschneider, J.; Matny, O.; Nguyen-Phuc, H.; Mago, R.; Raley, C.; Miller, M.E.; Silverstein, K.A.T.; Henningsen, E.; et al. Emergence of the Ug99 lineage of the wheat stem rust pathogen through somatic hybridisation. Nat. Commun. 2019, 10, 5068. [CrossRef] [PubMed]

74. Li, Y.X.; Wang, M.N.; See, D.R.; Chen, X.M. Ethyl-methanesulfonate mutagenesis generated diverse isolates of Puccinia striiformis f. sp. tritici. World J. Microbiol. Biotechnol. 2019, 35, 28. [CrossRef] 
75. Li, Y.X.; Xia, C.J.; Wang, M.N.; Yin, C.T.; Chen, X.M. Whole-genome sequencing of Puccinia striiformis f. sp. tritici mutant isolates identifies avirulence gene candidates. BMC Genom. 2020, 21, 247. [CrossRef]

76. Allen, R.G.; Pereira, L.S.; Raes, D.; Smith, M. Crop Evapotranspiration: Guidelines for Computing Crop Water Requirements; IrrigDrain UN-FAO: Rome, Italy, 1998; Volume 56, pp. 1-300.

77. Bregaglio, S.; Donatelli, M.; Confalonieri, R.; Acutis, M.; Orlandini, S. An integrated evaluation of thirteen modelling solutions for the generation of hourly values of air relative humidity. Theor. Appl. Climatol. 2010, 102, 429-438. [CrossRef]

78. Ephrath, J.E.; Goudriaan, J.; Marani, A. Modelling diurnal patterns of air temperatures, radiation, wind speed and relative humidity by equations for daily characteristics. Agric. Syst. 1996, 51, 377-393. [CrossRef]

79. Yin, X.; Kropff, M.J.; Mclaren, G.; Visperas, R.M. A non-linear model for crop development as a function of temperature. Agric. For. Meteorol. 1995, 77, 1-16. [CrossRef]

80. Scherm, H.; van Bruggen, A.H.C. Response surface models for germination and infection of Bremia lactucae, the fungus causing downy mildew of lettuce. Ecol. Model. 1993, 65, 281-296. [CrossRef]

81. Youn, E.; Jeong, M.K. Class dependent feature scaling method using naïve Bayes classifier for text data mining. Pattern Recognit. Lett. 2009, 30, 477-485. [CrossRef]

82. Su, L.; Wang, Q.; Wang, C.; Shan, Y. Simulation models of leaf area index and yield for cotton grown with different soil conditioners. PLoS ONE 2015, 10, e0141835.

83. Zhou, G.; Wang, Q. A new nonlinear method for calculating degree days. Sci. Rep. 2018, 8, 10149. [CrossRef]

84. Morinaga, T. Effect of alternating temperatures upon the germination of seeds. Am. J. Bot. 1926, 13, 141-158. [CrossRef]

85. Malaker, P.K.; Reza, M.M.A. Resistance to rusts in Bangladeshi wheat (Triticum aestivum L.). Czech J. Genet. Plant Breed 2011, 47, S155-S159. [CrossRef]

86. Tshewang, S.; Park, R.F.; Chauhan, B.S.; Joshi, A.K. Challenges and prospects of wheat production in Bhutan: A review. Exp. Agric. 2017, 54, 1-15. [CrossRef]

87. Vijayaraghavan, K.; Majumder, R.; Naithani, M.; Kapur, R.; Kaur, P. Status and opportunities for wheat seeds in India. Bangladesh, Nepal \& Bhutan. In Borlaug Global Rust Initiative 2018, Delivering Genetic Gain in Wheat; McCandless, L., Ed.; Borlaug Global Rust Initiative: New York, NY, USA, 2018; pp. 1-64. Available online: https://www.sathguru.com/news/wp-content/uploads/2018 /04/Wheat-in-South-Asia.pdf (accessed on 30 March 2021).

88. Wan, A.M.; Chen, X.M.; He, Z.H. Wheat stripe rust in China. Aust. J. Agric. Res. 2007, 58, 605-619. [CrossRef]

89. Tian, Y.; Zhan, G.M.; Chen, X.M.; Tungruentragoon, A.; Lu, X.; Zhao, J.; Huang, L.L.; Kang, Z.S. Virulence and simple sequence repeat marker segregation in a Puccinia striiformis f. sp. tritici population produced by selfing a Chinese isolate on Berberis shensiana. Phytopathology 2016, 106, 185-191. [CrossRef]

90. Joshi, L.M.; Srivastava, K.D.; Singh, D.V. Monitoring of wheat rusts in the Indian sub-Continent. Proc. Plant Sci. 1985, 94, 387-406.

91. Parmar, C.; Kaushal, M.K. Berberis aristata. In Wild Fruits; Kalyani Publishers: New Delhi, India, 1982; pp. 10-14.

92. Sharma-Poudyal, D.; Chen, X.M.; Wan, A.M.; Zhan, G.M.; Kang, Z.S.; Cao, S.Q.; Jin, S.L.; Morgounov, A.; Akin, B.; Mert, Z.; et al. Virulence characterization of international collections of the wheat stripe rust pathogen, Puccinia striiformis f. sp. tritici. Plant. Dis. 2013, 97, 379-386. [CrossRef]

93. Ali, S.; Rodriguez-Algaba, J.; Thach, T.; Sørensen, C.K.; Hansen, J.G.; Lassen, P.; Nazari, K.; Hodson, D.P.; Justesen, A.F.; Hovmøller, M.S. Yellow rust epidemics worldwide were caused by pathogen races from divergent genetic lineages. Front. Plant Sci. 2017, 8, 1057. [CrossRef] [PubMed]

94. Mirza, J.I.; Rattu, A.; Khanzada, K.A.; Ahmad, I.; Fetch, T. Race analysis of stem rust isolates collected from Pakistan in $2008-09$. In Proceedings of the Borlaug Global Rust Initiative 2010 Technical Workshop, St. Petersburg, Russia, 30-31 May 2010 ; p. 5.

95. Ahmed, M.; Anjum, M.A.; Naz, R.M.M.; Khan, M.R.; Hussain, S. Characterization of indigenous barberry germplasm in Pakistan: Variability in morphological characteristics and nutritional composition. Fruits 2013, 68, 409-422. [CrossRef]

96. Amini, M.H.; Hamdam, S.M. Medicinal plants used traditionally in Guldara District of Kabul, Afghanistan. Int. J. Pharmacog. Chin. Med. 2017, 1, 118. [CrossRef]

97. Rahmatov, M.; Eshonova, Z.; Ibrogimov, A.; Otambekova, M.; Khuseinov, B.; Muminjanov, H.L. Monitoring and evaluation of yellow rust for breeding resistant varieties of wheat in Tajikistan. In Meeting the Challenge of Yellow Rust in Cereal Crops Proceedings of the 2nd, 3rd and 4th Regional Conferences on Yellow Rust in the Central and West Asia and North Africa (CWANA) Region; Yahyaoui, A., Rajaram, S., Eds.; International Center for Agricultural Research in the Dry Areas: Alnarp, Sweden, 2012; pp. 318-325. Available online: https://www.researchgate.net/profile/Safar-Safavi-2/publication/320100382_Sources_of_resistance_to_ wheat_stripe_yellow_rust_resistance_in_elite_germplasm_in_Iran/links/59cdf2570f7e9b22563a7b58/Sources-of-resistance-towheat-stripe-yellow-rust-resistance-in-elite-germplasm-in-Iran.pdf (accessed on 30 March 2021).

98. Ashmawy, M.A.; Abu-Aly, A.A.M.; Youseef, W.A.; Shahin, A.A. Physiologic races of wheat yellow rust Puccinia striiformis f. sp. tritici in Egypt during 1999-2011, Minufiya. J. Agric. Res. 2012, 37, 297-305.

99. Draz, I.S. Pathotypic and molecular evolution of contemporary population of Puccinia striiformis f. sp. tritici in Egypt during 2016-2018. J. Phytopathol. 2019, 167, 26-34. [CrossRef]

100. McCallum, B.D.; Roelfs, A.P.; Szabob, L.J.; Grotha, J.V. Comparison of Puccinia graminis f.sp. tritici from South America and Europe. Plant Pathol. 1999, 48, 574-581. [CrossRef]

101. McHugh, M.L. Inter-rater reliability: The kappa statistic. Biochem. Med. 2012, 22, 276-282. [CrossRef]

102. Landis, J.R.; Koch, G.G. The measurement of observer agreement for categorical data. Biometrics 1977, 33, 159-174. [CrossRef] 